\title{
Selecting Superior Securities
}

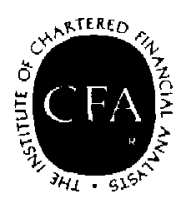

The Research Foundation of

The Institute of Chartered Financial Analysts 
(C) 1988 The Research Foundation of the Institute of Chartered Financial Analysts

All rights reserved. No part of this publication may be reproduced, stored in a retrieval system, or transmitted, in any form or by any means, electronic, mechanical, photocopying, recording, or otherwise, without the prior written permission of the copyright holder.

This publication is designed to provide accurate and authoritative information in regard to the subject matter covered. It is sold with the understanding that the publisher is not engaged in rendering legal, accounting, or other professional service. If legal advice or other expert assistance is required, the services of a competent professional should be sought.

From a Declaration of Principles jointly adopted by a Committee of the American Bar Association and a Committee of Publishers.

ISBN 10-digit: 0-943205-01-8 ISBN 13-digit: 978-0-943205-01-4

Printed in the United States of America 


\section{Mission}

The mission of the Research Foundation is to identify, fund and publish research material that:

- expands the body of relevant and useful knowledge available to practitioners;

- assists practitioners in understanding and applying this knowledge, and;

- enhances the investment management community's effectiveness in serving clients.

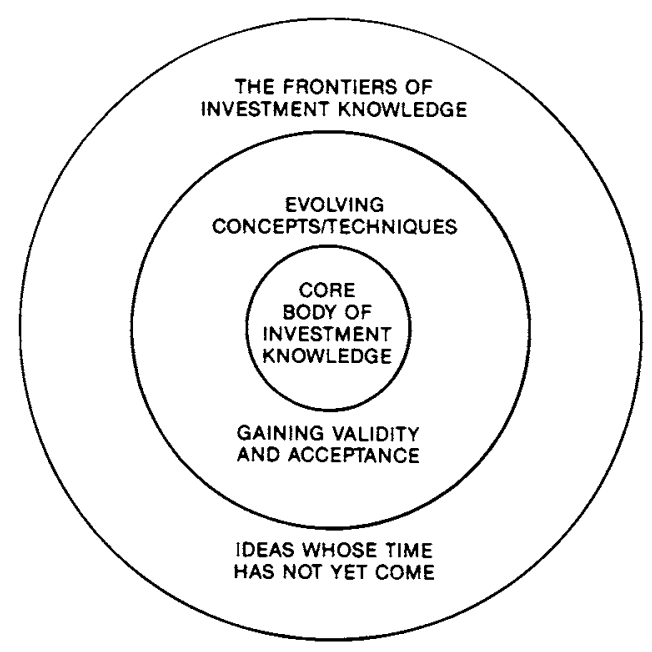

The Research Foundation of

The Institute of Chartered Financial Analysts

P.O. Box 3665

Charlottesville, Virginia 22903 


\section{Table of Contents}

List of Tables $\ldots \ldots \ldots \ldots \ldots \ldots \ldots \ldots$ ix

Foreword...................... xiii

Acknowledgements................. xv

Chapter 1. Introduction................. 1

Chapter 2. Defining the Set of the

Greatest Stock Market Winners.... . 5

Chapter 3. Fundamental and Technical

Characteristics of the

222 Winners ............... 9

Chapter 4. Trading Strategy Results:

1970-1983 .................. 25

Chapter 5. Trading Strategy Results:

1984-1986 ................ 37

Chapter 6. Implications and Conclusions....... 43

Tables ........................ 47

References ....................... 83 


\section{Tables}

Table 1. Listing of 222 Stock Market Winners in Chronological Order of Hypothetical Buy Dates..................... 49

Table 2. Price Appreciation and Length of Time Position Held for the 222 Greatest Stock Market Winners .............. 55

Table 3. Bank Holdings in the Sell, Buy, and Eight Preceding Quarters ............. 56

Table 4. Mutual Fund Holdings in the Sell, Buy, and Eight Preceding Quarters....... 57

Table 5. Investment Advisor Holdings in the Sell, Buy, and Eight Preceding Quarters ... 58

Table 6. Insurance Company Holdings in the Sell, Buy, and Eight Preceding Quarters ... 59

Table 7. Corporate Insider Transactions Among the 222 Greatest Winners in the Sell, Buy, and Eight Preceding Quarters....... 60

Table 8. Price-Book and Price-Earnings Among the 222 Greatest Winners in the Sell, Buy, and Eight Preceding Quarters....... 61

Table 9. Share Prices, Market Capitalizations, and Betas of the 222 Greatest Winners ... 62

Table 10. Relative Strength Ranks and Datagraph Ratings of the 222 Greatest Winners in the Sell, Buy, and Eight Preceding Quarters ...................6 63

Table 11. Industry Group Ranks of the 222 Greatest Winners in the Sell, Buy, and Eight Preceding Quarters ............. 64

Table 12. Pretax Profit Margins and Changes in Quarterly Earnings Among the 222 Greatest Winners in the Sell, Buy, and Eight Preceding Quarters ......... 65 
Tables (continued)

Table 13. Five-Year Earnings Growth Rates and Quarterly Changes for the 222 Greatest Winners in the Sell, Buy, and Eight Preceding Quarters ............ 66

Table 14. Common Shares Outstanding and Trading Volume for the 222 Greatest Winners in the Sell, Buy, and Eight Preceding Quarters .................. 67

Table 15. Ratio of Price on Buy Date to Maximum Price During Previous Two Years for the 222 Greatest Winners ........... 68

Table 16. Distribution of Cumulative Excess Holding Period Returns Earned by the Strategy Based on Nine Investment Screens ... 69

Table 17. Distribution of Cumulative Excess Holding Period Returns Earned by the Strategy Based on Nine Investment Screens Excluding Firms on the List of 222 Greatest Winners ................. 70

Table 18. Betas, Stock Market Capitalizations, Share Prices, and Shares Outstanding Among Firms Selected by the Strategy with Nine Investment Screens ..............71

Table 19. Distribution of Cumulative Excess Holding Period Returns Earned by the Strategy Based on All Nine Investment Screens Except for Price/Book Ratios Less than One ..................... 72

Table 20. Distribution of Cumulative Excess Holding Period Returns Earned by the Strategy Based on All Nine Investment Screens Except for Datagraph Ratings Greater than $70 \ldots \ldots \ldots \ldots \ldots \ldots \ldots . \ldots 73$ 


\section{Tables (continued)}

Table 21. Distribution of Cumulative Excess Holding Period Returns Earned by the Strategy Based on All Nine Investment Screens Except for Relative Strength and Datagraph Ratings Filters .......... 74

Table 22. Distribution of Cumulative Excess Holding Period Returns Earned by the Strategy Based on All Nine Investment Screens Except for the Three Earnings Filters and the Datagraph Ratings Filter......... 75

Table 23. Distribution of Cumulative Excess Holding Period Returns Earned by the Strategy Based Only on the Price/Book, Increasing Relative Strength and Accelerating Earnings Screens .............. 76

Table 24. Distribution of Cumulative Excess Holding Period Returns Earned by the Strategy Based on Nine Investment Screens (1984-86) . . . . . . . . . . . . . . . 77

Table 25. Distribution of Cumulative Excess Holding Period Returns Earned by the Strategy Based on All Nine Investment Screens Except for Price/Book Ratios Less than One $(1984-86) \ldots \ldots \ldots \ldots \ldots \ldots 78$

Table 26. Distribution of Cumulative Excess Holding Period Returns Earned by the Strategy Based on All Nine Investment Screens Except for Datagraph Ratings Less than $70(1984-86)$.................. 79

Table 27. Distribution of Cumulative Excess Holding Period Returns Earned by the Strategy Based on All Nine Investment Screens Except for Relative Strength and Datagraph Ratings Filters (1984-86). . . 80 


\section{Tables (continued)}

Table 28. Distribution of Cumulative Excess Holding Period Returns Earned by the Strategy Based on All Nine Investment Screens Except for the Three Earnings Filters and the Datagraph Ratings Filter (1984-86) . 81

Table 29. Distribution of Cumulative Excess Holding Period Returns Earned by the Strategy Based Only on the Price/Book, Increasing Relative Strength and Accelerating Earnings Screens (1984-86). . . . . . . . 82 


\section{Foreword}

The Research Foundation has been involved in practitioner-oriented research for more than 20 years, publishing or sponsoring a diverse assortment of monographs, proceedings, research papers, and books to broaden the knowledge and understanding of investment professionals. In 1986, the Foundation reaffiliated itself with the Institute of Chartered Financial Analysts to meet future needs more effectively. Now extensively reorganized, the Foundation intends to spark nothing less than a research renaissance.

The Research Foundation's mission is clearly stated: to identify, fund, and publish high-quality research material that expands the body of useful and relevant knowledge available to practitioners; assist practitioners in understanding and applying this knowledge; and contribute to the investment management community's effectiveness in serving clients.

The Foundation will continue to emphasize research that is of practical value to investment professionals. At the same time, it will explore new and challenging areas of research to provide members of the investment community with the latest knowledge about their rapidly-evolving profession.

Consistent with the Research Foundation's mission, this monograph makes a significant contribution to the evolving literature on market efficiency. The efficient market hypothesis has been at the center of investment theory for decades. In the late 1950s and early 1960s, researchers began debating whether stock prices exhibited random behavior. By 1970, a preponderance of academic research suggested that capital markets are informationally efficient- - that investors could not systematically outperform very naive investment strategies, such as buying and holding a market index portfolio. It seemed that technical and fundamental research, based on publicly-available information, would improve investment performance marginally at best. Since then there has been a growing volume of academic litera- 
ture which sheds serious doubt on this theory. Researchers began to uncover instances of market anomalies-or cases where investors could beat well-accepted benchmarks using publicly available information. At present, there is no concensus on whether markets are efficient or whether systematic patterns in stock returns can be exploited to earn excess market returns.

In this monograph, Reinganum discusses whether analyzing the characteristics of past stock market winners can yield significant insights into successful investment strategies. Unlike earlier research that isolates a particular attribute-such as price/earnings ratio or size-and then investigates its associated return behavior, Reinganum takes the opposite tack in this monograph: He singles out stocks with exceptionally high returns to see whether these firms share any common attributes. His view is that if history does repeat itself, these common attributes may provide the basis for a fruitful investment strategy.

Reinganum's topic and experimental design are consistent with the Research Foundation's mission. We are grateful to Dr. Reinganum for his contribution to the body of knowledge. 


\section{Acknowledgements}

This research spanned the course of two years. I benefited from discussion with Nai-Fu Chen, Kim Dietrich, Wayne Ferson, Larry Harris, Al MacGregor, Bill O'Neil, Jack Treynor, Rob Vishny, and Mark Weinstein. A special thanks is owed to Chuck D'Ambrosio, who carefully read and constructively critiqued earlier versions of this research. Partial funding and the research support provided by William O'Neil \& Company are gratefully acknowledged. I would like to acknowledge my appreciation for the research support provided by the University of Chicago during my sabbatical year (1985-86) and by the University of Southern California during the 1986-87 academic year. I also acknowledge the financial support of the Research Foundation of the Institute of Chartered Financial Analysts. Naturally, all the views and any of the errors are those of the author.

Marc R. Reinganum 


\section{Introduction}

In the late 1950s and early 1960 s, researchers began debating whether stock prices exhibited random behavior. Some claimed that stock price changes are unpredictable, with one article reporting that a pattern of simulated stock market prices generated by random numbers looked remarkably similar to patterns of actual stock market prices (Roberts 1959). This view was not universally accepted. For example, Alexander (1961) presented evidence suggesting that stock price changes are not completely random and that stock prices exhibit distinguishable trends. He proposed simple trading rules that would exploit these alleged trends. Later work by Fama and Blume (1966) disputed these findings and reported that Alexander's simple trading rules did not produce economically significant profits. By the mid-1960s and early 1970s, a preponderance of academic research supported the hypothesis that capital markets are informationally efficient (Fama 1970). This research suggested that investors could not systematically outperform very naive investment strategies, such as buying and holding a market index portfolio. It seemed that technical and fundamental research, based on publicly available information, would improve investment performance marginally at best, and probably not at all. It began to appear that throwing darts to select stocks would be just as effective.

By the late 1970s and early 1980s this simple view of 
investment performance was again subjected to serious doubt. Drawing on earlier work by Nicholson (1960), Basu (1977) reported that portfolios comprising stocks with low price-earnings ratios outperformed portfolios with high price-earnings ratios by about 7 percent per year, even after returns were adjusted for risk. Banz (1981) and Reinganum (1981) presented even more dramatic findings: stocks with very small market capitalizations outperformed those with large capitalizations by about 20 percent annually. Other investment anomalies, characterizing peculiar patterns in the timing of stock returns, were also discovered. These ranged from a month-of-the-year, or January, effect (Keim 1983), to a week-of-the month effect (Ariel 1987), to a day-of-the-week effect (French 1980; Gibbons and Hess 1981), and even included an hour-of-the-day effect (Harris 1986). Although each of these studies focused on a different problem, they shared at least one common conclusion: Investors may be able to beat well-accepted benchmarks using publicly available information. Of course, it is still debated whether such superior performance is the result of deficiencies in the benchmark or informational inefficiencies in the stock market.

This study discusses whether analyzing the characteristics of past stock market winners can yield significant insights into successful investment strategies. Unlike earlier research that isolates a particular attribute (such as $\mathrm{P} / \mathrm{E}$ or size) and then investigates its associated return behavior, this study takes the opposite tack, singling out stocks with exceptionally high returns to see whether these firms share any common attributes. If history does repeat itself, these common attributes may provide the basis for a fruitful investment strategy.

This research differs in its data as well as in its experimental design. Most of the data for this study come from the Datagraph books (William O'Neil \& Co.), which are sold primarily to institutional investors and report a host of fundamental and technical information for firms that trade on the listed exchanges 
and the OTC markets. ${ }^{1}$

The Datagraph books offer a much wider choice of potential candidates for common attributes among stock market winners than do the Center for Research in Security Prices (CRSP) or COMPUSTAT data. Whereas there are many ways to define a "stock market winner," the list of winners considered in this research is garnered from another O'Neil publication, The Greatest Stock Market Winners: 1970-1983, which contains 272 episodes of explosive price appreciation for companies trading on the New York Stock Exchange (NYSE), American Stock Exchange (AMEX), and over-the-counter (OTC) markets. ${ }^{2}$

Chapter 2 summarizes the price performances of the "greatest winners." Chapter 3 analyzes the behaviors of the technical and fundamental variables during the period of rapid price appreciation. If hindsight were foresight, these are the changes an analyst would like to have foreseen. Changes in the technical and fundamental indicators in the periods prior to this rapid appreciation are also characterized. Any common changes are taken to suggest a trading strategy; and results from a trading rule based on these changes are presented in Chapter 4. The trading rule results are presented for the period overlapping the initial analysis (1970-83). In Chapter 5, results for the trading rule are computed for a validation sample during 1984-86, a period completely outside that of the original sample. The final chapter summarizes the major findings.

\footnotetext{
${ }^{1}$ For this research, William O'Neil \& Co. provided a specially formatted computer tape containing the information on NYSE and AMEX firms from the Datagraph books (published weekly by William O'Neil \& Co., Los Angeles). This is the first time William O’Neil \& Co. has made these proprietary data available for an academic study.

'William O'Neil \& Co. The Greatest Stock Market Winners: 1970-1983. Los Angeles: William O'Neil \& Co., 1984.
} 


\section{Defining The Set of the Greatest Stock Market Winners}

The universe of winners considered in this research consists of any firm contained in The Greatest Stock Market Winners: 1970-1983. To be considered for inclusion on the list of great winners, a company typically had to at least double in value within a calendar year. The list included few exceptions to this guideline, and not all companies that doubled in value were selected. ${ }^{1}$ In this research, the list of greatest winners-272 firms-was merged with a file containing historical information on 2,279 NYSE and AMEX companies. These data were published in various issues of O'Neil's Datagraph covering the period $1970-83$. Of the 272 winning cases, 222 could be matched with the Datagraph information. The two numbers differ because (1) the historical data file does not contain OTC companies, whereas the list of greatest winners does; and (2) the

\footnotetext{
${ }^{I} \mathrm{O}$ 'Neil personnel employed criteria other than price appreciation to choose firms. However, such criteria are not explicitly stated. Based on the University of Chicago's CRSP tapes, there are 4,049 occurrences of an NYSE or AMEX firm doubling in value within a given calendar year during the 1970-1983 period. For example, one additional criterion seemingly applied to stocks by O'Neil personnel is related to the price per share of a stock. In O'Neil's universe of 272 firms, fewer than 5 percent sold for less than $\$ 10$ a share. If one eliminated from the list of 4,049 firms those selling for less than $\$ 10$, the list would dwindle to 1,311 companies. Given the customer base subscribing to this publication, such a price level screen is not all that surprising. Furthermore, it does not bias this analysis. At worst, it might caution one against applying the findings from this research to those stocks selling for less than $\$ 10$.
} 
CUSIP (Committee on Uniform Securities Identification Procedures) numbers of some companies could not be matched because of changes in the companies' names. The performance characteristics did not seem to change significantly for this pared-down list. For the complete list of 272 winners, the price appreciation averaged 361 percent; for the matched list of 222 winners, it averaged 349 percent. Table 1 lists the 222 winners, with their stock market performances and hypothetical buy and sell dates. The hypothetical buy and sell dates were assigned $e x$ post and were not generated from actual stock market recommendations. The number of weeks between the hypothetical purchase and sale varied from company to company, as shown in Table 1.

Price appreciation data for the 222 winners are summarized in Panel A of Table 2. The mean unadjusted return of 349 percent was pulled up by the performance of two stocks with astronomical price advances (4,009 percent and 2,554 percent); the median unadjusted return was 237 percent. Thus, 111 of the 222 winners increased in value by at least 237 percent. Further, one-fourth of these firms earned a return of more than 370 percent, and more than 95 percent of the sample at least doubled in value.

The data in Panel A were not adjusted for movements in the stock market as a whole. The data in Panel B reflect this adjustment: The returns of the S\&P 500 Index over the appropriate time periods were subtracted from the price appreciations of the individual securities. The mean adjusted return was 318 percent; the median was 209 percent.

Panel $\mathrm{C}$ shows how many weeks elapsed between the buy and sell dates for these firms. Half of the firms were held for less than 60 weeks. One-tenth of the firms were held for more than three years; only 5 percent of the firms were held for less than 26 weeks.

Regardless of the precise criteria by which companies merited inclusion in The Greatest Stock Market Winners, the perfor- 
mance of these firms would seem exceptional by any standard. The unadjusted gains averaged 349 percent over calendar periods that typically ranged between 6 months and 3 years; the market-adjusted appreciations averaged 318 percent. In the next chapter, the firms' financial conditions in the buy quarter are compared to those in the sell quarter and to those in the quarters immediately preceding the buy signal. 


\section{Fundamental and Technical Characteristics of the 222 Winners}

This section analyzes the concurrent and antecedent attributes of the 222 greatest winners. Analysis of the concurrent attributes reveals the changes in financial condition, apart from the rapid price appreciation, that occurred in firms between the buy and sell dates. These changes suggest the variables an analyst should concentrate on forecasting. A careful examination of the antecedent attributes should identify common changes in financial conditions among the greatest winners that occurred prior to the buy quarter. In principle, such changes could form the basis of a reliable trading strategy based on publicly available information.

To aid in presenting the numerous variables in the Datagraph files, each variable is classified into one of five categories. ${ }^{1}$ The first category is "smart money" and includes the behavior of professionally-managed funds and corporate insiders; the second contains valuation measures, such as price/book and priceearnings ratios; the third includes technical indicators, such as relative strength; the fourth consists of accounting earnings and profitability measures; and the final category contains several miscellaneous variables that did not seem to fit into the other four groups.

\footnotetext{
${ }^{1}$ These categories are strictly the author's and are not part of the O'Neil data.
} 


\section{The "Smart Money" Variables}

The "smart money" variables refer to the stock holdings of professionally-managed investment funds and corporate insiders of four types: (1) banks, (2) mutual funds, (3) investment advisors, and (4) insurance companies. For each of these groups, O'Neil reports the number of institutions holding a particular issue, as well as the aggregate holdings of these institutions as a percentage of the outstanding common stock. Labelling these data smart money variables may be somewhat facetious. ${ }^{2}$ Nonetheless, they disclose the actions of professional money managers, whose compensation may at least in part depend on the performance of the funds they oversee. For corporate insiders, O'Neil reports the number of buyers and sellers, as well as the number of shares they bought and sold. Even if they are not clairvoyant, corporate insiders and professional money managers are probably a well-informed group of investors.

Bank holdings among the 222 greatest stock market winners are shown in Table 3 for the buy quarter, the sell quarter, and the eight quarters preceding the buy date. Changes between the buy and sell quarters indicate what happens to bank holdings during the period of rapid price appreciation. At the beginning of the price advance-the buy quarter-the number of banks owning some shares in these 222 winners averages slightly greater than 12 (see Panel A of Table 3 ).

Bank sponsorship in these 222 companies was not evenly distributed. One-tenth of these firms were owned by more than 35 banks in the buy quarter, and at least one-fourth of these companies were not in the portfolios of any banks. Bank sponsorship, as measured by the percentage of outstanding shares held by these institutions, present a similar picture. On average, banks owned 6.46 percent of the shares of the 222 winners in the general skepticism about the ability of these funds to outperform the market. 
buy quarter (Panel B, Table 3). Again, the figures reveal an uneven ownership pattern. The banks owned more than 10 percent of the stock in one-fourth of the firms but no stock for another fourth of the sample.

In the sell quarter, after the major price advance, the pattern of bank sponsorship is clearly altered. On average, the number of banks owning stock in each company nearly doubled from 12.3 to 23.0 , with the median jumping from 3 to 11 . Although bank sponsorship was still not evenly distributed among the 222 winners, 185 of them were now held by at least one bank; in the buy quarter, banks owned 21 fewer.

Whereas the average number of banks holding each stock rose dramatically, the increase in the stake of each company owned by the banks was more modest, from 6.46 percent on average in the buy quarter to 8.09 percent in the sell quarter. At the end of the period of rapid price appreciation, more banks held these companies than at the beginning, and the banks in aggregate owned a greater proportion of these companies.

Although these data do not indicate whether the banks jumped on the bandwagon or merely followed it, bank ownership data in the eight quarters preceding the buy quarter suggest that they were not the bellwether of the subsequent surge in stock prices. In the year preceding the price advance, the average number of banks owning shares in each of these winners hovered around 10. Banks increased their holdings in these companies; the percentage of outstanding shares held by banks crept up in the two quarters before the buy date. These changes in bank sponsorship, however, are not nearly as great as those between the buy and sell dates. Bank sponsorship was not a leading indicator of great impending price changes.

Mutual fund holdings behaved similarly to those of banks (Table 4). Between the buy and sell dates, the number of mutual funds investing in each of the 222 winners nearly doubled, jumping from an average of 10.6 funds per company to 19.6 . Although the number of mutual funds investing in each company 
was not evenly distributed, a greater proportion of the 222 winners was held by at least one mutual fund than was held by at least one bank. Of the 222 winners, 206 and 221 were in the portfolio of at least one mutual fund in the buy and sell quarters, respectively. The aggregate holdings of mutual funds jumped more dramatically between the buy and sell dates than did that of banks. On average, mutual funds owned 4.91 percent of each of the 222 winners in the buy quarter and 7.88 percent of the outstanding stock in the sell quarter. Thus, as a group, mutual funds substantially increased their positions in the 222 winners between the buy and sell dates.

Prior to the buy quarter, mutual fund sponsorship was stable. The average holdings by mutual funds of the 222 winners ranges between 4 percent and 5 percent of the outstanding common stock. The average number of mutual funds investing in one of these companies was around 9. No apparent change in these figures presaged the impending price explosion. Thus, the actions of mutual funds, like those of banks, did not foretell the subsequent large price changes, though these changes were correlated contemporaneously with changes in mutual fund sponsorship.

Investment advisor holdings displayed the same basic patterns as those of mutual funds and banks but were more pronounced. Between the buy and sell dates, the number of investment advisors owning the 222 winners more than doubled, increasing from an average of 9.3 advisors per company to 20.9 (Panel A of Table 5). The change in investment advisor ownership was just as dramatic, more than doubling on average. The average percent of outstanding stock held by investment advisors rose from 7.2 in the buy quarter to 14.9 in the sell quarter. As a group, investment advisors concentrated their holdings in fewer companies than banks or mutual funds. Of the 222 winners, only 103 and 145 were in the portfolio of at least one investment advisor in the buy and sell quarters, respectively.

Nevertheless, the investment advisor sponsorship data did 
not foretell the big price change. Although sponsorship by investment advisors increased slightly in the quarter or two preceding the buy date, the increases are miniscule compared to those observed between the buy and sell dates. The past behavior of investment advisors was not a good predictor of future stock price movements.

Compared to banks, mutual funds, and investment advisors, insurance companies are the small institutional players in the stocks of these 222 winners. The number of insurance companies investing in these firms in both the buy and sell quarters was relatively small (Table 6). The average ownership stake of insurance companies was also much smaller than that of the other institutions; it increased from an average of 1.94 percent of the outstanding stock in the buy quarter to 2.61 percent in the sell quarter. Insurance companies tracked the other three groups in that the pattern of their ownership holdings prior to the buy date was relatively stable. Hence, as a group, they did not presage the impending stock price explosion.

Several general observations may be drawn from the professionally-managed funds as a group. If hindsight were foresight, one would like to have known of the impending significant increases in the sponsorship of stock held by banks, mutual funds, and investment advisors. On average, these groups of professionally-managed funds increased their ownership stakes in the 222 winners between the buy and sell dates by 25,60 , and 107 percent, respectively. At the conclusion of the rapid price advance, these funds were substantially invested in great winners. Prior to the buy quarter, their ownership claims tended to rise, but only slightly. The big increase in sponsorship occurred as the prices began to escalate sharply, indicating that professional money managers may participate in, but do not prophesy, the extraordinary price appreciation.

Corporate insiders are another group that may be privy to generally unavailable information about a company's prospects. Tracking their transactions may reveal this information and 
provide a guideline to profitable trading. Indeed, several prior studies suggest that insider trading does predict future price changes (Jaffe 1974; Seyhun 1986). Insider trading data for these 222 companies, however, do not indicate any pattern of significant changes. Panel A of Table 7 summarizes statistics for the number of insiders purchasing stock. In most companies, no corporate insiders were buying stock either prior to the large price advance or after it.

The selling transactions seem equally uninformative. One might expect insider selling to subside prior to the major price advance. In fact, insider selling among these 222 companies actually increased slightly before the advance, rising from an average of 0.84 insider sales per company to 1.38. After the large price advance, insider selling was also slightly greater, which is consistent with expectations. Of course, insider buying was somewhat greater as well, which runs contrary to expectations. If insiders do know of impending major economic events that are likely to affect stock prices, their own trading did not reveal that information (at least for these 222 firms). Thus, direct purchases and sales by corporate insiders did not tip off investors to the major price advances that were ahead.

Whereas the smart money variables may reflect the actions of well-informed investors, the evidence suggests that well-informed investors did not predict major price advances: (1) The transactions of corporate insiders did not lead or were contemporaneous with large price changes; (2) the actions of professional money managers did not lead the large price changes but were a contemporaneous reaction; and (3) significant shifts in institutional ownership were contemporaneous with large price movements.

\section{Valuation Measures}

The five different valuation variables used in this study were: (1) price/book ratios; (2) price-earnings ratios; (3) stock price level; (4) stock market capitalization; and (5) beta. Prior re- 
search reports a relation between each of these variables and performance. This section investigates the behavior of each of these variables among the 222 greatest winners.

Price/book ratios compare the market values of equity to their book values. A ratio of less than 1.0 indicates that a company's market value is less than its book value and might suggest that the stock is underpriced. Among the 222 winners, 164 were selling for less than book value in the buy quarter. The median price/book ratio among the 222 winners was 0.60 , and the average was 0.95 in the buy quarter (Panel A of Table 8 ). In the sell quarter, the average and median price/book values were 2.64 and 2.24. The results for the sell quarter are not surprising, because the group of firms analyzed had just experienced a major price advance. In the two quarters preceding the buy date, however, 183 and 184 of the 222 subsequent winners were selling at a market price less than their book values. Although a price/book value less than one may not identify perfectly a stock market winner, a price/book value less than one was a common characteristic among these 222 winners. This evidence suggests that one aspect of an investment strategy should be to isolate firms that sell below book value.

The distribution of price-earnings ratios $(\mathrm{P} / \mathrm{E})$ is displayed in Panel $\mathrm{B}$ of Table 8 . In the buy quarter, the average $\mathrm{P} / \mathrm{E}$ ratio was 13.6 ; the median $\mathrm{P} / \mathrm{E}$ ratio, which is less influenced by the extreme values, was 10. Most previous research (e.g., Basu 1977; Reinganum 1981) posits an inverse relation between $\mathrm{P} / \mathrm{E}$ ratios and performance: the lower the $\mathrm{P} / \mathrm{E}$, the higher the returns. Clearly, the $\mathrm{P} / \mathrm{E}$ ratios for this set of 222 winners did not tend to be very small. In fact, only one-tenth of these firms possessed $\mathrm{P} / \mathrm{E}$ ratios less than 5 in the buy quarter. In the quarters preceding the buy date, the mean $\mathrm{P} / \mathrm{E}$ ratios fluctuated around 11 and 12. This evidence does not contradict earlier research, although it clearly indicates that very low $\mathrm{P} / \mathrm{E}$ ratios were not a necessary ingredient of a successful investment strategy. 
Whereas prior research showed that small, low-priced stocks outperformed large, high-priced ones, this group of 222 winners was not characterized by either low stock prices or small stock market capitalizations. Among the 222 winners, the average share price on the buy date is $\$ 27.69$ (Panel A of Table 9 ). The median price was slightly greater than $\$ 24$. Only 9 companies sold for less than $\$ 10$ a share. These companies were not particularly small as measured by stock market capitalization (number of shares times price per share). The mean capitalization was $\$ 484.3$ million, and was heavily influenced by the one-time inclusion of IBM at a market capitalization of $\$ 37$ billion. The median capitalization was $\$ 120.1$ million. Numbers presented in Reinganum (1983) indicate that this figure would fall in the seventh decile of capitalization rankings. Only one of the 222 winners had a market capitalization less then $\$ 10$ million on the buy date, and only 12 had capitalizations less than $\$ 20$ million. As a rule, these companies are not so small. One might find this characteristic somewhat surprising given the volume of research on the small-firm effect. As with $\mathrm{P} / \mathrm{E}$ ratios, this evidence suggests that small firms, whether measured by share price or stock market capitalization, were not a necessary component of a successful investment strategy. A small-size investment screen was not justified by the data from these 222 winners.

Modern financial theory maintains that high-risk investments are expected to earn high returns. A stock's beta is a frequently-cited measure of risk, and is formally derived within the framework of the capital asset pricing model. Beta measures a security's risk relative to the market portfolio. In principle, the extraordinary returns earned by these 222 winners might simply be compensation for their extreme riskiness. The data, however, do not support such an interpretation. The average and median beta among these firms is $1.14 .{ }^{3}$ Fewer than 5 percent of the companies possessed betas in excess of 2.0 . In fact, the betas for 80 percent of the firms fell between 0.52 and 1.78 . 
Although the group of firms was slightly riskier than the market, the additional risk did not account for their extraordinary returns.

Investigation of valuation measures revealed those investment characteristics that should be stressed, and those that need not be highlighted. For example, the evidence from these 222 winners showed that during this period, one should have selected companies whose market value was less than their book value, a finding which is neither startling nor new. The more surprising discovery is that these 222 winners were not low-priced stocks, low-P/E companies, or small market capitalization firms. ${ }^{4}$ This evidence does not contradict the findings of other research. Rather, it demonstrates that low-priced stocks, low-P/E companies, or small capitalization firms may be an integral part of some successful investment strategy, but none is needed in every successful strategy.

\section{Technical Indicators}

Three technical indicators are considered in this section: (1) relative strength rank, (2) Datagraph rating, and (3) industry group rank. The relative strength rank of a stock ranges from 1 (the lowest) to 99 (the highest). The relative strength of a particular stock is calculated using a weighted average of the percentage price changes of the stock over the previous 12 months. The price change in the most recent quarter receives a weight of 40 percent, and the other three quarters receive weights of 20 percent each. The Datagraph rating is based on a

\footnotetext{
${ }^{3}$ Betas are calculated using weekly returns during the period two years prior to the buy date. The proxy for the market portfolio is a value-weighted index of all New York and American Stock Exchange companies.

${ }^{4}$ One cannot rule out the possibility that $\mathrm{O}^{\prime}$ Neil personnel implicitly (it is not stated in the publication) applied some of these criteria to define a great winner. For example, given their institutional customers, it might make commercial sense to exclude most companies selling at a price less than $\$ 10$ or whose market capitalizations are smaller than $\$ 20$ million.
} 
proprietary O'Neil formula that assigns weights to "reported earnings (primary operating), capitalization, sponsorship, relative strength of stock, price-volume characteristics, group rank and other factors." The Datagraph rating also ranges from 1 (the lowest) to 99 (the highest). Finally, industry group rank is based on the average price appreciation of firms within each industry. Unlike the relative strength rank and Datagraph rating, the highest industry group rank is 1 and the lowest is about 200 .

Table 10, Panel A, contains the relative strength ranks of the 222 winners. In the buy quarter, the mean relative strength was 90.2 , and the median rank was 93 . More than 95 percent of the sample 212 firms possessed relative strength measures in excess of 70 in the buy quarter. These figures suggest that, as a group, the prices of these firms had begun to increase compared to the rest of the market.

This phenomenon is also apparent in the relative strength ranks in the quarters immediately preceding the buy date. Both the mean and median relative strength ranks jump by about 12 between the month prior to the buy quarter (buy-1) and the buy quarters. In fact, the relative strength measures for 170 of the 222 winners increased between these two dates. These data suggest two common characteristics of a successful investment strategy: (1) seek firms with relative strength ranks of at least 70; and (2) try to identify firms that exhibit positive changes in their relative strength from the prior quarter.

The Datagraph ratings of the 222 winners also tend to be high in the quarter of the buy date (Panel B, Table 10). The mean rating in the buy quarter was 78.3. and the rating for 188 firms exceeded 70 . The Datagraph ratings, as with the relative strength measures, also show increases-the mean and median ratings each increase by about 10 between the buy- 1 and buy quarters. The ratings for 175 of the 222 winners increased over this period. Increases in Datagraph ratings overlap significantly with increases in relative strength between the buy-1 and buy dates. Of the 175 companies with Datagraph increases, 147 also 
registered increases in relative strength. A common characteristic among this set of great winners was a Datagraph rating in excess of 70 in the buy quarter. Although one might also consider incorporating positive changes in Datagraph ratings into an investment strategy, these changes seem captured by changes in relative strength.

The last technical indicator considered was industry group rank. This measure did not impart much additional information to that already gleaned from relative strength. In the buy quarter, the industries into which these 222 winners fell were ranked in relative strength: At least 75 percent of the sample were in the top half of the industry rankings (Table 11). Further, the relative performance of these industries improved prior to the buy date. Given the relative strength rankings, these findings are not surprising, as it is well known that price movements among firms in a given industry tend to be positively correlated. Given that the price changes of a particular firm tend to be positive (the relative strength measure), one should not be surprised to discover that the prices of other firms in that industry tend to rise. Of the 139 firms whose industry group rank improved between the buy-1 and buy date, 115 also registered improved relative strength. The industry group rank variable shows that these firms were in industries whose price appreciation was greater than those of most industries.

During this period, the technical indicators had the potential to lead major price movements. Information regarding relative strength seems to have been important: relative strength ratings greater than 70 and increasing seem to have been a common characteristic among winning firms. Datagraph ratings in excess of 70 were also prevalent among the 222 winners. Nevertheless, changes in Datagraph ratings and industry group ranks are common among these firms and seem to have been fairly well captured by changes in relative strength ratings.

\section{Earnings and Profitability Measures}

The variables in this category gauge a firm's health, as evaluated by standard accounting measures. Three of the variables-pretax margins, changes in quarterly sales, and changes 
in quarterly earnings-assess the firm's short-run performance. The fourth variable, a five-year quarterly earnings growth rate, offers a picture of the firm's financial health over a longer period. Unlike price data, accounting data are typically released with a lag. For example, fourth-quarter earnings may not be publicly released until sometime in the latter part of the first quarter, so it is likely that accounting information from the buy quarter may not be known until the following quarter. For this reason, only accounting information up through the buy-1 quarter should be considered to provide any leading indicators of the impending price advances.

The pretax profit margins of the 222 winners are presented in Panel A of Table 12. In the buy quarter, the average and median pretax margins were 12.7 and 11.2 percent, respectively. In the buy-1 quarter, these margins were slightly smaller, 12.3 and 10.8 percent, respectively. By the sell quarter, however, the pretax average and median profit margins increased to 14.5 and 13.0 percent. The pretax margins of these firms grew with the great run-up in price. Indeed, the nearly 2 percentage point increase in the pretax margins may have contributed to the price appreciation of these firms. Prior to the period of rapid price appreciation, the pretax profit margins gradually increased. The most pervasive feature of these data, however, is that 216 of the 222 winners had positive pretax margins in the buy quarter, and 215 had positive margins in the buy-1 quarter. This evidence clearly indicates that a positive pretax profit margin should be one of the selection screens in an investment strategy.

Percentage changes in quarterly earnings are shown in Panel B of Table 12 . The quarterly changes are not seasonally adjusted; they represent changes in raw accounting earnings. On average, quarterly earnings in the buy quarter rose nearly 45.9 percent from the previous quarter. Quarterly earnings of the buy- 1 quarter increased an average of 60.8 percent.

These average changes, however, are heavily influenced by several firms that experienced immense percentage changes in 
quarterly earnings. In the buy-1 quarter, the median percentage change in quarterly earnings was 14.1 percent, and about three-fourths of the 222 experienced quarterly changes of less than 42 percent. A most noticeable feature of these data are the changes between the buy- 2 and buy- 1 quarters. The accounting data from these quarters are the last that could be used as a leading indicator of the forthcoming price advance. Between the buy- 2 and buy- 1 quarters, the average change in quarterly earnings increased from 50.4 percent to 60.8 percent; the median changes mirrored this increase, rising from 3.0 percent to 14.1 percent. These data exhibit an acceleration-a positive change in the change in quarterly earnings. Thus, another investment rule suggested by these 222 winners is to seek out firms with a positive change in the change in quarterly earnings, that is, earnings acceleration.

The behavior of changes in quarterly sales (Panel A of Table 13) closely parallels that of changes in quarterly earnings, with both accelerating during the buy- 2 and buy- 1 quarters. The average rates of changes are positive and increasing. Sales during the buy-1 quarter rose by 11.8 percent on average over the previous quarter; the buy- 2 quarter increased an average of 6.7 percent. Prior to the buy- 2 quarter, the changes in quarterly sales did not exhibit any particular trend. In general, the information contained in the changes in quarterly sales is redundant of the information regarding the changes in quarterly earnings.

Earnings over a longer period of time, reflected in the fiveyear quarterly earnings growth rates, are shown in Panel $\mathrm{B}$ of Table 13. These rates are computed with five years of quarterly earnings data and then annualized. In the buy and buy1 quarters, the average growth rates were 23.0 percent and 21.6 percent, respectively, and the median growth rates were 17 and 16 percent, respectively. By the sell quarter, the average and median earnings growth rates increased dramatically to 38.2 and 30 percent, respectively. This increase may result because low rates from several years prior are compounded with high 
subsequent rates when growth rates are calculated. The net effect is a noticeable rise in the overall five-year quarterly earnings growth rate.

In the buy- 1 and previous quarters, the average five-year quarterly rate was very stable. In the buy-1 quarter, however, more than 85 percent of the firms had positive five-year quarterly earnings growth rates. This feature of the data from the 222 winners suggests an investment strategy that selects companies with positive five-year quarterly earnings growth rates.

\section{Miscellaneous Measures}

Three variables-common shares outstanding, average daily trading volume, and the ratio of the price on the buy date to the previous two-year high - did not fit well in the other categories and are described here. The first two of these variables are regularly reported in the O'Neil Datagraph books. The third is intended to reveal whether the 222 winners were selling near their highs or lows at the time of the hypothetical buy date.

The data for common shares outstanding are presented in Panel A of Table 14. In the buy quarter, the average number of shares outstanding among the 222 winners is about 13.8 million; the median is less, 5.7 million, because a few companies among the 222 had more than 100 million outstanding shares. In the sell quarter, both the average and median number of outstanding shares nearly doubled. This probably indicates that many of the firms split their shares of stock during the period of rapid price increase. In the period preceding the rapid increase, the number of shares outstanding appears relatively stable. Perhaps the only point about the data that might be relevant to an investment strategy is that nearly 90 percent of the firms had fewer than 20 million shares of stock outstanding. Thus, one might limit the firms selected by an investment strategy to those with fewer than 20 million outstanding shares of stock.

A noticeable feature in the average daily trading volume data is the doubling of shares traded between the buy and sell 
quarters (Panel B of Table 14). The average volume increased from 31,700 shares to 61,900 shares. Trading volume also increased between the buy- 1 and buy quarters, but showed very little change prior to the buy-1 quarter. Although many of these companies split their stock between the buy and sell dates, it is debatable that this phenomenon caused the increased trading; other factors may have been at work.

The ratio of the price on the buy date to the maximum price during the two previous years is one measure of whether these firms had fallen out of favor in the investment community. Stated differently, this variable measures the extent to which the extraordinary success of these 222 winners is due to a contrarian investment strategy. Generally speaking, contrarian strategies seem to select stocks which suffer substantial price declines. It is unlikely, however, that these stocks would be selected by a contrarian rule. On the buy date, more than half the winners were selling within 8 percent of their previous two-year high price (Table 15). Fourteen of these firms were selling at their high price for the past two years. Only one company sold at a price less than half its previous two-year high. More than 80 percent of the sample was selling within 15 percent of its previous two-year high. Clearly, these firms did not sell at low prices relative to their historical values. Indeed, just the opposite was true. An investment strategy that selected stocks that were selling within 15 percent of their maximum price during the previous two-year period would have reflected a common characteristic among these 222 stock market winners. 


\section{Trading Strategy Results: 1970-1983}

The number of variables collected by O'Neil could provide the basis for numerous potential investment strategies. In the previous section, nine variables were singled out as potential leading indicators of a substantial price expansion. ${ }^{1}$ From these nine variables alone, 512 (i.e., $2^{9}$ ) different possible investment strategies may be derived. Obviously, not all of these strategies are practical.

As a starting point, however, a strategy may be analyzed which is based on the nine technical and fundamental variables that either noticeably changed before the big price run-up or seemed to be pervasive among the winners; this strategy overlays nine investment screens on the data. The first strategy serves as a benchmark against which other trading rule results may be compared. The returns associated with several other trading rules are also computed. These strategies are not defined after an exhaustive search of all possible strategies, and thus it is not claimed that these are the best possible strategies. An investigation of these alternative strategies, however, reveals the sensitivity of the overall results to the inclusion or

\footnotetext{
${ }^{1}$ It is not being claimed that all nine variables are necessary for a successful investment strategy, nor is it implied that other variables may not be helpful. The analysis of the 222 winners did suggest, however, that these nine variables merit further investigation.
} 
deletion of key components from the strategy. The strategies also illustrate that lessons learned from the empirical regularities associated with the biggest winners may be applied profitably to a broader universe of companies.

The implementation of a trading rule is straightforward. After a buy signal is generated, a position in the stock is not assumed for 63 trading days (about 3 calendar months), which ensures that accounting information that is assumed to be known actually has been released. The stock is then purchased and held for two years. ${ }^{2}$ The cumulative holding period return is calculated through each of the eight quarters. To establish a performance benchmark, the cumulative holding period returns of each selected stock are compared to the cumulative returns of the S\&P 500 Composite Index (S\&P 500) over the same period. The difference between the returns of the security and the S\&P 500 is labelled an excess return. A buy signal for a particular company may be generated at multiple points in calendar time. In these cases, the returns for each buy signal are tracked separately.

The data used to generate a buy signal are contained on a tape supplied by William O'Neil \& Co which includes the fundamental and technical variables for 2,279 New York and American Stock Exchange firms over the $1970-1983$ period. This is the same period in which the characteristics of the 222 winners are delineated. The return data for the individual securities and the S\&P 500 are gathered from the files provided by CRSP.

Under the trading strategy using all 9 investment screens, a buy signal is issued for a firm when all of the following conditions are met:

1. The price/book ratio is less than 1.0. generated. 
2. The five-year growth rate based on quarterly earnings is positive.

3. Quarterly earnings are accelerating, that is, there is a positive change in the percentage change in quarterly earnings.

4. Pre-tax profit margins are positive.

5. There are fewer than 20 million common shares outstanding.

6. The relative strength rank of the stock is at least 70 .

7. The relative strength rank of the stock in the current quarter is greater than the rank in the previous quarter.

8. The O'Neil Datagraph rating is at least 70.

9. The stock is selling within 15 percent of its maximum price during the previous two years.

These nine investment screens were based on the common characteristics of O'Neil's 222 greatest stock market winners and applied to the universe of 2,279 firms contained on the large O’Neil tape.

For the 1970-83 period, the results of this composite trading strategy were impressive (Table 16): (1) It generated 627 buy signals for 406 different companies; (2) on average, the cumulative holding period returns of the selected securities exceed the equivalent return for the S\&P 500 in each of the eight quarters; (3) after one quarter these stocks appreciated in value by 9.66 percent, whereas the S\&P 500 appreciated by 1.64 percent (a differential of about 8 percentage points); (4) at the end of eight quarters, this performance differential averaged nearly 66 percentage points-the stocks selected by the investment strategy rose in value by nearly 81 percent, whereas the S\&P 500 registered gains of only about 15 percent; (5) these performance differentials were not generated by a few instances in which firms experienced huge price appreciation -in half of the instances, firms earned returns at least 49 percentage points greater than those of the S\&P 500 after eight quarters. Nearly 
one-fourth of the sample experienced returns 100 percentage points greater than those of the S\&P 500 after two years. In fact, after two years, 80 percent of the firms selected by this investment strategy had cumulative holding period returns greater than those of the S\&P 500 .

Even though these performance data are impressive, they may entail a serious bias. In particular, the 2,279 firms to which the nine investment screens were applied included the 222 greatest winners. Because the 222 greatest winners were used to design the nine investment filters, it is possible that the nine screens applied to the 2,279 firms might simply map back onto the 222 greatest winners, imparting an upward bias in the return statistics. To eliminate this bias, any firm on the list of 222 greatest winners was excluded from the investment strategy over the entire 1970-83 time period. To the extent that the samples of the 222 winners and the other firms were correlated, some subtle biases may remain, but they may be eliminated by applying the trading strategy in other time periods.

The investment strategy results, exclusive of the 222 winners, are shown in Table 17. The strategy generated 453 buy signals for 319 different companies over the 1970-83 period. As might be expected, the average excess return was less when the firms experiencing meteoric price appreciation were removed from the universe. Nonetheless, the strategy still performed very well. The selected firms outperformed the S\&P 500 by more than 50 percentage points on average over a two-year interval, with the individual firms appreciating in value by more than 65 percentage points, whereas the S\&P 500 managed gains of only about 15 percent. Further, the excess returns were not concentrated among a few firms. In more than 79 percent of the cases, these firms outperformed the S\&P 500 over a two-year period. The firms selected by these nine investment screens earned excess holding period returns of about 23 percent per year.

28 The higher returns earned by the investment strategy need 
not be abnormal in the sense that they may just reflect the compensation for bearing additional risk; however, risk, at least as measured by historical betas, does not explain the average 23 percent per year excess returns earned by firms selected by the investment strategy. The betas computed with weekly returns for individual securities and the S\&P 500 averaged only 1.03 in the two-year period preceding the buy date (Panel A of Table 18). Half of the firms had betas of less than 1.0. The betas for 80 percent of the selected companies ranged in value between 0.45 and 1.66. Similar values for betas were obtained when the proxy for the market was a value-weighted NYSE-AMEX market index.

In earlier research, Banz (1981) and Reinganum (1981) demonstrate that the average returns of small firms exceed the average returns of large firms, even after controlling for differences in risk as measured by beta. ${ }^{3}$ Firm size in these studies was measured by a company's stock market capitalization; that is, the price per share times number of shares outstanding. One explanation for the annual excess holding period returns of nearly 23 percent reported here is that the investment strategy is tilted in favor of small stocks. In a more recent study, Reinganum (1983) reported that his smallest group of firms possessed a median stock market capitalization of $\$ 4.6$ million. These very small firms earned about 32 percent per year on average over the 1963-82 period, unadjusted for market movements. After adjustment for market movements, the excess returns of these very small firms were of about the same magnitude as the excess returns associated with the investment strategy reported here.

As shown in Panel B of Table 18, the firms selected by this investment strategy were not small by Banz's and Reinganum's standards. The median stock market capitalization of the 
selected firms was $\$ 102.3$ million. In the Reinganum (1983) study, this figure was closest to the median capitalization of his seventh decile portfolio, $\$ 119$ million, which was in the upper half of the capitalization ranking that included all New York and American Stock Exchange companies. Firms in the seventh decile portfolio earned average returns of 15.6 percent per year over the 1963-82 period. Firms selected by the nine investment screens in the 1970-83 period earned an average of 30.6 percent in the first year after they were bought. Thus, firms selected by this investment strategy apparently outperformed a portfolio of firms of about the same median stock market capitalization. Stated differently, the excess returns earned by this investment strategy cannot be attributed to the small-firm effect. This is not particularly surprising because fewer than 5 percent of the firms would be considered very small. Even if stock market capitalizations are a very good proxy for risk (see Chan and Chen 1986), they do not explain the success of the investment strategy outlined here.

The distribution of the two components of stock market capitalization, share prices and shares outstanding, are presented in Panels $\mathrm{C}$ and $\mathrm{D}$ of Table 18. The median share price of the selected firms was $\$ 26.25$. The share prices for one-fourth of the firms exceeded $\$ 34.82$. Only 8 percent of the firms sold for less than $\$ 10.00$ on the day they were purchased. Clearly, the selected companies were not low-priced stocks either. The median number of shares outstanding was slightly less than 4 million. The dispersion in outstanding shares was fairly large, with 80 percent of the companies falling in the range between 1.2 million shares and 12.8 million shares.

The nine criteria of the investment strategy were determined from an analysis of the 222 greatest stock market winners, and the sensitivity of the strategy results to all nine criteria was first assessed by examining the effects of deleting several of the strategy's key components. The first screen dropped was the requirement that the price/book ratios be less than 1.0 ; the 
other eight filters were still applied. Naturally, this less restrictive investment strategy applied to more securities, generating 686 buy signals for 445 firms during the 1970-83 period. The resulting trading rule returns are displayed in Table 19.

Clearly, without the price/book ratio filter, return performance declined. After one year, the chosen firms experienced excess holding period returns of 14.6 percent; they appreciated in value by about 22.5 percent in one year, whereas the S\&P 500 advanced by only about 7.9 percent. After two years, the excess holding period returns were 30.6 percent; the individual securities averaged gains of 47.8 percent over two years, and the S\&P 500 increased by about 17.2 percent. Although these performance figures were still impressive, they suggested that the price/book ratio criterion plays a central role in the overall investment strategy. The deletion of the price/book ratio filter reduced the performance of the trading rule by about 7 percentage points per year, and the average excess holding period returns dropped over a two-year period from about 50 percent to 30 percent.

Although the price/book ratio rule seemed important to the strategy, the requirement that a stock possess a Datagraph rating greater than 70 was not critical. The eight investment screens remaining after the Datagraph rating requirement was deleted identified 935 buying opportunities for 547 different companies during the 1970-83 period. The excess holding period returns for this strategy averaged 21.2 percent and 45.9 percent after one and two years, respectively (Table 20). By comparison, the results that included the Datagraph rating restriction equalled 23.7 percent and 50.6 percent over one- and two-year periods. The difference was a mere 1.5 percentage points.

The Datagraph ratings contributed so little to the holding period returns of the portfolio strategy because the investment filters identified in this paper largely overlap the variables O'Neil used in calculating the ratings. This should not be too surprising, because the technical and fundamental variables chosen for the 
trading rules were gleaned from an analysis of 222 companies classified as great stock market winners by $\mathrm{O}^{\prime} \mathrm{Neil}$. It is a welcome finding that the Datagraph rating was of limited significance, because the other eight filters may be computed from data that were in the public domain and not proprietary.

A stock's relative strength is a potentially significant component of the trading strategy. Relative strength entered in the strategy in three ways. First, it entered directly because only securities with relative strength ranks greater than 70 could be considered. Second, it was a factor because only the previous quarter's relative strength rankings were eligible for selection. Finally, it entered indirectly through the security's Datagraph rating, which is based in part on relative strength.

In an attempt to purge the results of effects associated with relative strength, the consequence of removing these three variables from the investment strategy was estimated. Their removal left a trading rule with 6 screens, which dramatically increased the number of buy signals to 3,911 for 864 different companies during the $1970-83$ period. The excess cumulative holding period returns associated with this strategy averaged 17.3 percent and 36.0 percent after one and two years, respectively (Table 21). The cumulative holding period returns of the securities, unadjusted for changes in the S\&P 500, averaged 23.9 percent and 51.5 percent, respectively.

Clearly, relative strength alone did not drive the success of the investment strategy, but the strategy suffered when relative strength was not included as a criterion. The return performance was diminished by 6.4 percentage points in the first year relative to the returns earned by all nine investment screens. In other words, the returns were reduced an additional 4.9 percentage points beyond the 1.5 percentage points reduction associated with the elimination of just the Datagraph rating criterion. These findings are consistent with the conjecture that relative strength may be used to identify stock market winners.

The next sensitivity analysis was performed by eliminating 
the criteria pertaining to earnings. Earnings entered the trading strategy in three direct ways and one indirect way. A company was eligible for inclusion only if (1) its five-year quarterly earnings growth rate is positive; (2) the pretax profit margins were positive; and (3) earnings were accelerating; that is, this quarter's percentage change in quarterly earnings was greater than last quarter's percentage change. Because earnings are a component of the Datagraph rating, this criterion was also deleted.

With these deletions, five investment screens remained. During the $1970-83$ period, these five filters identified 4,901 buy signals for 1,199 different companies. After one year, the excess cumulative holding period returns was 17.1 percent (Table 22). By the end of the second year, the average excess cumulative holding period return advanced to 34.5 percent. Even without the earnings screens, the remaining filters revealed an ability to select stocks whose performance exceeded the S\&P 500 . Nonetheless, at the margin, the earnings filters did appear to contribute to the success of the overall trading rule. Without the earnings filters, the performance dropped from 23.7 percent to 17.1 percent after the end of one year. Perhaps coincidentally, the decline in performance associated with the omission of the earnings criteria was nearly identical to that associated with the omission of the relative strength criteria. In any case, this evidence suggests that earnings may be helpful in formulating a successful investment strategy.

The final sensitivity analysis took a different tack. Instead of subtracting certain criteria from the set of nine filters, each investment screen was applied to the original set of 222 winners and the three screens that produce the highest median returns were selected. For example, from among the 222 winners, those with price-book values less than 1.0 had a median return of 260 percent; the median return of all 222 winners was 237 percent. The three investment screens with the highest median returns among the 222 winners were: 
1. The price/book ratio is less than 1.0 (260 percent).

2. Quarterly earnings are accelerating; that is, there is a positive change in the percentage change in quarterly earnings (253 percent).

3. The relative strength rank of the stock in the current quarter is greater than the rank in the previous quarter (253 percent).

A buy signal was generated whenever the three criteria were satisfied. As might be expected, many more buy signals were generated with only three filters than with nine. The threescreen filter rule generated 13,080 buy signals compared to the 453 buy signals generated by the nine-filter rule. Clearly, the other six investment screens severely limited the selection of firms. But did these other six screens seem to matter?

The performance results for the investment strategy with only three filters are shown in Table 23 . These results should be compared to those in Table 17. Perhaps surprisingly, the strategy with only three screens still did well relative to the S\&P 500 index. After one year, these selected firms averaged excess holding period returns of 14.6 percent; they appreciated in value by 22.9 percent, whereas the S\&P 500 advanced by only 8.3 percent. After two years, the average excess holding period returns were 32.0 percent.

Although these performance results are impressive, they fall short of the excess holding period returns earned when all nine investment screens were applied. For example, with nine investment screens, the average excess holding period returns were 23.7 percent after one year instead of 14.6 percent. Similarly, after two years, the strategy with nine investment screens produced an average excess holding period return of about 50 percent as opposed to 32 percent. At the margin, the other six investment rules seemed to improve performance. Thus, although the results should not be construed to mean that these three investment screens are the three best filters, the 
results do suggest that all nine of the investment rules are not

redundant. In other words, it seems unlikely that any one of the investment rules will yield better performance results than all nine jointly. 


\section{Trading Strategy Results: 1984-1986}

Although the 1970-83 trading rule results excluded companies classified by William O'Neil \& $\mathrm{Co}$. as great stock market winners, the sample was not completely independent of the 222 winners, because the 222 winners were selected expost from the 1970-83 period. One way to investigate whether the trading rule performs as described is to validate it against a set of firms in a different time period. In principle, the validation outcomes help reveal which components of the trading rule are stable over time and which seem to be specific to the $1970-83$ period.

Ideally, the number of observations in the validation sample would be about the same as those in the original sample, so that the power of the inferences drawn from the two samples would be equivalent. Unfortunately, these data do not lend themselves to this design. The original sample encompasses 14 years and the validation sample covers only three years. ${ }^{1}$ Thus, the validation evidence should not be interpreted as either definitively confirming or refuting the stability of the trading rule strategy but should be viewed as just one additional piece of evidence regarding a strategy's efficacy. A complete validation would require many additional years of data.

The excess returns of the complete trading strategy with nine investment screens during 1984-86 are shown in Table 24.

${ }^{1}$ Data for the validation sample were supplied on a separate tape by William O'Neil \& Co. in early 1987. 
To avoid double-counting the same security in this short period, a buy signal was issued only the first time the nine conditions are met. In this three-year period, 59 buy signals were generated. The performance results, although somewhat smaller than those of the 1970-83 period, were still impressive. The securities that passed the nine filters experienced excess returns of 22.2 percent after one year and 36.7 percent after two years on average; the raw cumulative returns of these securities, unadjusted for changes in the S\&P 500, averaged 43.2 percent and 86.3 percent after one and two years, respectively. These sample averages were based on a small number of observations. Only 25 buy signals generated in 1984 could be tracked for a full eight quarters, and only 46 buy signals could be followed for four quarters. The levels of excess returns during 1984-1986 were lower than in the 1970-1983 period. In the earlier period, the cumulative excess holding period returns averaged 23.7 percent after one year, and in the later period they equalled 22.2 percent. A more noticeable difference appeared over a two-year holding period. The $1970-83$ results revealed a cumulative excess holding period return of 50.6 percent whereas the 198486 performance averaged 36.7 percent. Nonetheless, the validation evidence suggests that the trading rule does work, even completely out of sample.

The sensitivity analyses performed in the previous chapter were repeated on the 1984-86 data to investigate whether the modified trading rules applied to the validation sample exhibit changes in the same direction as observed in the original sample. The first criterion eliminated was the requirement that price/ book ratios be less than one. When this condition was relaxed, the number of buy signals jumped from 59 to 215 . Clearly, the price/book ratio criterion was a stringent one in this period. ${ }^{2}$

\footnotetext{
${ }^{2}$ The price/book ratios of companies are generally higher in the 1980s than they were in the 1970s. An alternative trading strategy might investigate companies with price/ book ratios that are low relative to the rest of the securities instead of only those companies whose ratios fall below 1.0, a natural though somewhat arbitrary cutoff.
} 
Table 25 contains the revised results for the trading strategy without the price/book ratio condition. The validation evidence reveals a pattern similar to the one in the original sample. With the deletion of a price/book ratio screen, investment performance suffered. After one year, the average excess cumulative return dropped to 11.4 percent from 22.2 percent; after two years, the average declined to 14.0 percent from 36.7 percent. $^{3}$ Thus, evidence from both the validation sample and the original sample is consistent with the conjecture that low price/book ratios are an important component of the trading strategy.

The Datagraph ratings, at the margin, did not matter very much in the original sample, and the same pattern is found in the validation sample (Table 26). When the restriction that a company's Datagraph rank be greater than 70 was lifted, the remaining eight investment screens identified 112 buying opportunities in the 1984-86 period. The excess holding period returns averaged 18.8 percent and 31.1 percent after one and two years, respectively. These average excess cumulative returns were slightly lower than those reported when the Datagraph restriction was imposed. Again, this similarity in returns results probably because many of the variables underlying the Datagraph rating are directly incorporated into the trading strategy.

Table 27 reports the effects of removing the two relative strength requirements as well as the Datagraph filter. When these conditions were eliminated, 157 buy signals were generated during 1984-86. After four quarters, the performance of this subset of trading rules was nearly 6 percentage points less than the performance of the complete set. After one year, the

\footnotetext{
${ }^{3}$ In this table, as in some of the tables that follow, one observes that several companies possess excess returns smaller than -100 percent. These numbers are neither typographical errors nor programming errors. An excess return is defined as the difference between the security's holding period return and the equivalent return for the S\&P 500. Whereas the holding period return for a security is bounded by -100 percent, this difference is not. For example, in Table 25 the excess holding period return for one company equalled -120.3 percent after two years, which resulted from that company's stock market value falling by about 70 percent during a period which the S\&P 500 rose by about 50 percent.
} 
six remaining filters yielded an average excess return of 16.6 percent, as opposed to an average of 22.2 percent for all nine filters. The direction and magnitude of this change in the validation sample is consistent with the evidence in the original sample after one year.

Whereas the direction of the change after two years in the validation sample was consistent with the evidence in the 197083 sample, the magnitude of the change was much smaller. In the validation, the performance after eight quarters declined to 30.5 percent on average from 36.7 percent, a difference slightly greater than 6 percentage points. In the $1970-83$ sample, this difference averaged about 14 percentage points.

In the validation, the effects on the two-year excess returns of deleting the relative strength conditions were not very dramatic, for two possible reasons: (1) relative strength is not a stable component of this strategy, at least for a two-year horizon; or (2) the 1984-86 result with respect to relative strength is an outlier and does not accurately reflect the long-run influence of relative strength on investment performance. Before one can confidently conclude which of these interpretations is correct, data from additional years will need to be collected and analyzed.

Deleting the three earnings filters and the Datagraph requirement in the validation samples yielded results qualitatively similar to those obtained in the original sample. The remaining five investment screens earmarked 245 securities as eligible for purchase in the 1984-86 period. Without the earnings filters, investment performance declined (Table 28), decreasing after four quarters from 22.2 percent to 13.3 percent. At the end of eight quarters, the average excess cumulative returns also diminished; the remaining five filters generated returns of 21.3 percent, whereas the complete set of nine yielded 36.7 percent. These patterns of change were similar to those documented in the original sample. Thus, the validation sample evidence also suggests that the earnings filters play a key role in the trading strategy. 
The final permutation included only three investment screens: (1) price/book ratios less than 1.0; (2) increasing relative strength ranks; and (3) accelerating quarterly earnings. During 1984-86, these three filters signalled 518 buying opportunities. On average, the cumulative excess holding period returns reached 8.5 percent and 16.3 percent after one and two years, respectively (Table 29), as compared to returns of 22.2 percent and 36.7 percent for the set of nine filters. In the original sample, as in the validation sample, this set of three filters did not perform as well as the complete set of nine. The performance of these three filters, however, comes closer to that of the nine filters in the 1970-83 sample than in the 1984-86 sample.

The validation sample seemed to corroborate many of the results discovered in the 1970-83 sample. The set of nine investment rules produced significant excess holding period returns in the 1984-86 period. After two years, the average excess holding period return equalled 36.7 percent, and the standard error of this estimate equalled 8.7 percent. In addition, the sensitivity analyses in the validation sample qualitatively upheld many of the findings from the original sample. In the validation and the original sample, investment performance suffered when the price/book ratio criterion was excluded. Further, at the margin, the Datagraph ratings were shown to affect performance very little, if at all, in both samples. Evidence from the validation and original samples suggested that the exclusion of the three earnings filters adversely influenced investment performance. Also, in both samples the set of three investment criteria (price/book less than 1.0, increasing relative strength, accelerating quarterly earnings) performed well but not quite as well as the full set of nine criteria. The relative performance of the three criteria, however, was not as great in the validation as in the original sample.

The 1984-86 validation results diverged from the results obtained in the original 1970-83 period only with respect to the two relative strength filters. In their absence, investment per- 
formance during 1970-83 declined by about 6 percentage points after one year and 14 percentage points after two. In the validation, the results after one year were consistent with the 1970-83 evidence, with performance declining by about 6 percentage points. The cumulative results after two years, however, remained at about 6 percent in the $1984-86$ period; the elimination of the relative strength criteria did not further reduce investment performance in the second year. Whether this means that relative strength is not a stable component of the trading strategy over a two-year horizon or whether it means that this short validation period is uncharacteristic of the effect of relative strength over longer time periods may only be resolved after additional data from other years is analyzed. Nonetheless, the validation results are consistent with the original sample for the overall trading strategy with nine investment screens. 


\section{Implications and Conclusions}

This research explored the anatomy of 222 stock market winners from 1970-83. The dissection highlighted several financial features that may aid managers in their quest for the wellbehaved portfolio. If hindsight were foresight, one would like to know of the impending changes in institutional holdings. Institutional interest in a stock seems to increase along with that stock's price. For example, the ownership stake of investment advisors more than doubled on average at the conclusion of the 222 price advances. An accurate forecast of pretax profit margins would also be valuable. The pretax profit margins of the 222 winners rose during the period of rapid price appreciation. By the sell quarter, their margins increased by about 2 percent on average. In addition, the growth rates based on five years of quarterly earnings data advanced from an average of 23 percent during the buy period to 38.2 percent at the sell period. This change in the five-year earnings growth rate reflects the fact that low growth rates from earlier years are replaced with the high earnings growth rates during the period of the price expansion. Indeed, the changes in earnings growth rates and profit margins probably fueled, at least in part, the price advances.

Other distinctive features in the anatomy of the winners revealed themselves prior to the rapid price appreciation. These financial features do not require that a portfolio manager have a crystal ball with which to gaze into the future. Rather, they are 
characteristics that may be gleaned from publicly available information. For example, the winners generally sell at a price less than their book value prior to their substantial price advances. In addition, the quarterly earnings of the winners are accelerating in the quarters preceding their price rise; that is, there is a positive change in the percentage change in quarterly earnings. Prior to their buy dates, the relative strengths of the winners are high and increasing, which reflects the incipient stages of the explosive price changes. In all, nine features are singled out. They are:

1. The price/book ratio is less than 1.0.

2. The five-year growth rate based on quarterly earnings is positive.

3. Quarterly earnings are accelerating, that is, there is a positive change in the percentage change in quarterly earnings.

4. Pre-tax profit margins are positive.

5. There are fewer than 20 million common shares outstanding.

6. The relative strength rank of the stock is at least 70 .

7. The relative strength rank of the stock in the current quarter is greater than the rank in the previous quarter.

8. The O'Neil Datagraph rating is at least 70 .

9. The stock is selling within 15 percent of its maximum price during the previous two years.

These nine investment criteria are not judged on the basis of the statistical sophistication (or the lack thereof) underlying their discovery, but on the basis of the results they produce in other samples. To this end, the nine characteristics form the basis for a simple trading strategy which, applied to a universe of 2,279 New York and American Stock Exchange firms over the 1970-83 period, significantly outperformed the S\&P 500 index. For further validation, the trading rule is applied to data from a 
completely different period. During 1984-86, the nine investment screens selected securities that appreciated in value by 86.2 percent on average, while the S\&P 500 increased on average by 49.5 percent. These results are not quite as impressive as those from the $1970-83$ period, but they do indicate that the trading rule captures stable elements of a successful investment strategy.

One implication of this research perhaps stands above all others: there is no one correct way to select superior securities. The absence of certain characteristics from the trading strategy merit mention, viz, those associated with superior performance in various studies of investment anomalies. This trading strategy is not tilted in favor of stocks with small market capitalizations, or with low share prices or, with low price-earnings ratios. It is not a contrarian strategy in that it does not select companies with substantial previous price declines. Indeed, only firms that are selling near their maximum price for the two previous years are eligible for inclusion. It is not claimed that low $\mathrm{P} / \mathrm{E}$ stocks or stocks with small market capitalizations do not perform well. Substantial evidence shows that these investment strategies do select superior securities over long periods of time. Despite the absence of these other characteristics, however, the trading strategy defined in this study performs exceptionally well. The excess returns earned by this strategy are economically significant and suggest that there may be more than one way to skin the performance cat. 


\section{Tables}


TABLE 1

\section{LISTING OF 222 STOCK MARKET WINNERS IN CHRONOLOGICAL ORDER OF HYPOTHETICAL BUY DATES}

\begin{tabular}{|c|c|c|c|c|}
\hline \multirow{2}{*}{ Company } & \multicolumn{2}{|c|}{ Hypothetical Hypothetical } & \multirow[b]{2}{*}{ Performance } & \multirow{2}{*}{$\begin{array}{c}\text { Weeks } \\
\text { Held }\end{array}$} \\
\hline & & Sell Date & & \\
\hline A M F INC & 21AUG70 & 30JUN72 & $167 \%$ & 97 \\
\hline ECHLIN INC & 21AUG70 & 26JAN73 & 257 & 127 \\
\hline CLOROX CO & 28AUG70 & 12JAN73 & 329 & 124 \\
\hline HOUSE OF FABRICS INC & 28AUG70 & 26MAR71 & 123 & 30 \\
\hline PETRIE STORES CORP & 28AUG70 & 04FEB73 & 303 & 127 \\
\hline QUAKER STATE OIL REFNG & 28AUG70 & $05 \mathrm{JAN} 73$ & 231 & 123 \\
\hline KAUFMAN \& BROAD INC & 04SEP70 & 09JUN72 & 145 & 92 \\
\hline RUBBERMAID INC & 11SEP70 & 22SEP72 & 280 & 106 \\
\hline SCHEIB EARL INC & 18SEP70 & 07JUL72 & 378 & 94 \\
\hline DEVELOPMENT CORP OF AMER & $230 \mathrm{CT} 70$ & 09JUN72 & 557 & 85 \\
\hline NEW PROCESS COMPANY & $230 \mathrm{CT} 70$ & 14JAN72 & 304 & 64 \\
\hline STANDARD MOTOR PROD CL A & $300 \mathrm{CT} 70$ & 21JAN72 & 208 & 64 \\
\hline DISNEY PRODUCTIONS & 06NOV70 & 12JAN73 & 249 & 114 \\
\hline BAKER INTL CORP & 20NOV70 & 15DEC72 & 214 & 108 \\
\hline CIRCLE K CORP & 20NOV70 & 23JUN72 & 221 & 83 \\
\hline MCDONALDS CORP & 20NOV70 & 16FEB73 & 438 & 117 \\
\hline RITE AID CORP & 20NOV70 & 23JUN72 & 429 & 83 \\
\hline COLECO INDUSTRIES INC & 27NOV70 & 04AUG72 & 260 & 88 \\
\hline N C H CORP & $27 \mathrm{NOV} 70$ & $02 \mathrm{FEB} 73$ & 196 & 114 \\
\hline OVERNITE TRANSPORTATION & 27 NOV70 & 21APR72 & 238 & 73 \\
\hline T R E CORP & $27 \mathrm{NOV} 70$ & 04FEB72 & 214 & 62 \\
\hline SCOTTYS INC & 18DEC70 & 14APR72 & 397 & 69 \\
\hline JOHNSON \& JOHNSON & 31DEC70 & 18AUG72 & 121 & 85 \\
\hline BAUSCH \& LOMB INC & 12MAR71 & 25FEB72 & 222 & 50 \\
\hline LEASEWAY TRANSPORTATION & 26MAR71 & 23JUN72 & 119 & 65 \\
\hline MAGIC CHEF INC & 07MAY71 & 03MAR72 & 74 & 43 \\
\hline FLEETWOOD ENTERPRISES & 14MAY71 & 14JUL72 & 142 & 61 \\
\hline WINNEBAGO INDUSTRIES INC & 21MAY71 & 07JUL72 & 377 & 59 \\
\hline MASCO CORP & 27AUG71 & 02JUN72 & 90 & 40 \\
\hline ANTHONY INDUSTRIES & 26NOV71 & 28JUL72 & 202 & 35 \\
\hline AUGAT INC & 26NOV71 & 18AUG72 & 159 & 38 \\
\hline HALLIBURTON COMPANY & 26NOV71 & 19JAN73 & 140 & 60 \\
\hline PONDEROSA INC & 26NOV71 & 05JAN73 & 198 & 58 \\
\hline HEWLETT-PACKARD CO & 03DEC71 & $16 \mathrm{FEB} 73$ & 103 & 63 \\
\hline MOBILE HOME IND INC & 03DEC71 & 26MAY72 & 111 & 25 \\
\hline SONY CORP AMER SHS NEW & 14JAN72 & 12JAN73 & 198 & 52 \\
\hline MARION LABORATORIES INC & 04FEB72 & $11 \mathrm{AUG} 72$ & 88 & 27 \\
\hline A S A LTD & 16FEB73 & 15FEB74 & 272 & 52 \\
\hline HOMESTAKE MINING CO & 23NOV73 & 18JAN74 & 109 & 8 \\
\hline
\end{tabular}




\section{TABLE 1 - Continued}

\section{LISTING OF 222 STOCK MARKET WINNERS IN CHRONOLOGICAL ORDER OF HYPOTHETICAL BUY DATES}

\begin{tabular}{|c|c|c|c|c|}
\hline Company & $\begin{array}{c}\text { Hypothetical } \\
\text { Buy Date } \\
\end{array}$ & $\begin{array}{c}\text { Hypothetical } \\
\text { Sell Date } \\
\end{array}$ & Performance & $\begin{array}{c}\text { Weeks } \\
\text { Held } \\
\end{array}$ \\
\hline M C A INCORPORATED & $06 \mathrm{DEC} 74$ & $100 \mathrm{CT} 75$ & $227 \%$ & 44 \\
\hline PITTSTON CO & 20DEC74 & 25JUL75 & 113 & 31 \\
\hline UNITED TECHNOLOGIES CORP & $20 \mathrm{DEC} 74$ & 04JUL75 & 82 & 28 \\
\hline MARK CONTROLS CORP & 24JAN75 & 18FEB77 & 389 & 108 \\
\hline MOORE MCCORMACK RES INC & 24JAN75 & 25JUL75 & 186 & 26 \\
\hline PALL CORP & 31JAN75 & 01AUG75 & 167 & 26 \\
\hline TANDY CORP & 31JAN75 & 27FEB76 & 357 & 56 \\
\hline DIAMOND SHAMROCK CORP & 14FEB75 & 09JUL76 & 183 & 72 \\
\hline E SYSTEMS INC & 14FEB75 & 28JAN77 & 370 & 102 \\
\hline GENERAL DYNAMICS CORP & $28 \mathrm{FEB} 75$ & 20JUN75 & 104 & 16 \\
\hline ENTEX INC & 09MAY75 & $140 \mathrm{CT} 77$ & 218 & 127 \\
\hline DAYTON HUDSON CORP & 16MAY75 & 26MAR76 & 139 & 45 \\
\hline HARRIS CORP DEL & $170 \mathrm{CT} 75$ & 15SEP78 & 418 & 152 \\
\hline NORTHROP CORPORATION & 07NOV75 & 18MAR77 & 141 & 71 \\
\hline ALLIS CHALMERS CORP & 19DEC75 & 24SEP76 & 134 & 40 \\
\hline TELEDYNE INC & $26 \mathrm{DEC} 75$ & $010 \mathrm{CT} 76$ & 269 & 40 \\
\hline BEST PRODUCTS INC & 09JAN76 & 21JUL78 & 350 & 132 \\
\hline JOHNSON CONTROLS INC & 23JAN76 & 12MAY78 & 347 & 120 \\
\hline GEARHART INDUSTRIES INC & 12MAR76 & 18AUG78 & 374 & 127 \\
\hline NATIONAL PRESTO IND & 12MAR76 & $010 \mathrm{CT} 76$ & 104 & 29 \\
\hline MITCHELL ENERGY \& DEV. & 07MAY76 & 21JAN77 & 171 & 37 \\
\hline WOODS PETROLEUM CORP & 14MAY76 & 04FEB77 & 207 & 38 \\
\hline UNITED INDUSTRIAL CORP & 11JUN76 & 27MAY77 & 109 & 51 \\
\hline WASTE MANAGEMENT INC & 10SEP76 & 21 NOV 80 & 900 & 219 \\
\hline ELGIN NATIONAL IND & 17SEP76 & 22APR77 & 98 & 31 \\
\hline BALLY MFG CORP & $150 \mathrm{CT} 76$ & 08SEP78 & 564 & 99 \\
\hline M G M GRAND HOTELS INC & $05 \mathrm{NOV} 76$ & 08SEP78 & 283 & 96 \\
\hline SAVIN CORP & 19 NOV76 & 16SEP77 & 226 & 43 \\
\hline PETRO LEWIS CORP & 03DEC76 & 07MAR80 & 850 & 170 \\
\hline BALDOR ELECTRIC CO & 25MAR77 & 29SEP78 & 342 & 79 \\
\hline HUMANA INC & 17JUN77 & 19JUN81 & 1325 & 209 \\
\hline COMMUNITY PSYCHIATRIC CN & 22JUL77 & 24JUN83 & 2554 & 309 \\
\hline FLIGHTSAFETY INTL INC & 29JUL77 & 15MAY81 & 965 & 198 \\
\hline DOME MINES LTD & 02SEP77 & $240 \mathrm{CT} 80$ & 576 & 164 \\
\hline STORAGE TECHNOLOGY CORF & 02SEP77 & 08SEP78 & 398 & 53 \\
\hline DATAPOINT CORP & $280 \mathrm{CT} 77$ & 17APR81 & 755 & 181 \\
\hline BROWN FORMAN INC CL B & 04NOV77 & 19NOV82 & 369 & 263 \\
\hline PALL CORP & 04NOV77 & 09JAN81 & 411 & 166 \\
\hline SCOA INDUSTRIES INC & 04NOV77 & 08SEP78 & 186 & 44 \\
\hline
\end{tabular}


TABLE 1 - Continued

\section{LISTING OF 222 STOCK MARKET WINNERS IN CHRONOLOGICAL ORDER OF HYPOTHETICAL BUY DATES}

\section{Company}

SMITHKLINE BECKMAN CORP

FLUKE MFG CO INC

HILTON HOTELS CORP

DOME PETROLEUM LTD

LA QUINTA MOTOR INNS INC

M/A-COM INC

TELEDYNE INC

FAIRCHILD INDUSTRIES

VEECO INSTRUMENTS INC

A $V$ X CORP

BOEING CO

PRIME COMPUTER INC

TORO CO

MEASUREX CORP

NUCOR CORP

WANG LABS INC CL C CONV

UNITRODE CORPORATION

RESORTS INTL CL A

AMDAHL CORP

STANDARD OIL OF OHIO

TEXAS OIL \& GAS CORP

TUBOS DE ACERO DE MEXICO

CROWN CENTRAL PETE CL A

PENNZOIL CO

TOSCO CORP

TOYS R US

LEAR PETROLEUM CORP

COMPUTERVISION CORP

GULF CANADA LTD

CANADIAN MARCONI CO

CHARTER CO

GERBER SCIENTIFIC INC

GLOBAL MARINE INC

HEILEMAN G BREWING

HELMERICH \& PAYNE INC

MATERIALS RESEARCH CORP

G C A CORPORATION

WESTERN CO OF NO AMER

FLUOR CORP

\begin{tabular}{|c|c|c|c|}
\hline $\begin{array}{c}\text { Hypothetical } \\
\text { Buy Date }\end{array}$ & $\begin{array}{l}\text { Hypothetical } \\
\text { Sell Date }\end{array}$ & Performance & $\begin{array}{c}\text { Weeks } \\
\text { Held }\end{array}$ \\
\hline 04NOV77 & 08SEP78 & $135 \%$ & 44 \\
\hline 11 NOV77 & 22AUG80 & 246 & 145 \\
\hline 11 NOV77 & 25AUG78 & 190 & 41 \\
\hline 18NOV77 & 22FEB80 & 576 & 118 \\
\hline 25NOV77 & 08JAN82 & 753 & 216 \\
\hline 20JAN78 & 29MAY81 & 950 & 175 \\
\hline 20JAN78 & 19JUN81 & 503 & 178 \\
\hline 27JAN78 & 09JAN81 & 371 & 154 \\
\hline 27JAN78 & 09JAN81 & 656 & 154 \\
\hline 03FEB78 & 15SEP78 & 119 & 32 \\
\hline 03FEB78 & 02FEB79 & 182 & 52 \\
\hline 17FEB78 & 05JUN81 & 1595 & 172 \\
\hline 17FEB78 & 20APR79 & 207. & 61 \\
\hline 24FEB78 & 22JUN79 & 152 & 69 \\
\hline 10MAR78 & 12JUN81 & 550 & 170 \\
\hline 10MAR78 & 05JUN81 & 1352 & 169 \\
\hline 17MAR78 & 050СТ79 & 195 & 81 \\
\hline 24MAR78 & 15SEP78 & 836 & 25 \\
\hline 21APR78 & 08SEP78 & 139 & 20 \\
\hline 08DEC78 & 28NOV80 & 348 & 103 \\
\hline 08DEC78 & 28NOV80 & 525 & 103 \\
\hline 22DEC78 & 28SEP79 & 260 & 40 \\
\hline 12JAN79 & 08FEB80 & 328 & 56 \\
\hline 12JAN79 & 05DEC 80 & 167 & 99 \\
\hline 19JAN79 & 13JUL79 & 278 & 25 \\
\hline 19JAN79 & 12AUG83 & 1671 & 238 \\
\hline 26JAN79 & $22 \mathrm{FEB} 80$ & 330 & 56 \\
\hline 09FEB79 & 24APR81 & 1235 & 115 \\
\hline 09FEB79 & 07MAR80 & 366 & 56 \\
\hline 16FEB79 & 01FEB80 & 147 & 50 \\
\hline 02MAR79 & 15JUN79 & 387 & 15 \\
\hline 02MAR79 & 14NOV80 & 489 & 89 \\
\hline 02MAR79 & 02JAN81 & 808 & 96 \\
\hline 02MAR79 & $210 \mathrm{CT} 83$ & 831 & 242 \\
\hline 02MAR79 & 02JAN81 & 348 & 96 \\
\hline 02MAR79 & 02JAN81 & 507 & 96 \\
\hline 09MAR79 & 12JUN81 & 844 & 118 \\
\hline 16MAR79 & $28 \mathrm{NOV} 80$ & 551 & 89 \\
\hline 11 MAY79 & 21NOV80 & 434 & 80 \\
\hline
\end{tabular}


TABLE 1

\section{LISTING OF 222 STOCK MARKET WINNERS} IN CHRONOLOGICAL ORDER OF HYPOTHETICAL BUY DATES

\begin{tabular}{|c|c|c|c|c|}
\hline Company & $\begin{array}{c}\text { Hypothetical } \\
\text { Buy Date }\end{array}$ & $\begin{array}{l}\text { Hypothetical } \\
\text { Sell Date }\end{array}$ & Performance & $\begin{array}{l}\text { Weeks } \\
\text { Held } \\
\end{array}$ \\
\hline COMMODORE INTL LTD & 18MAY79 & $17 J U N 83$ & $4009 \%$ & 213 \\
\hline OCEAN DRILLING \& EXPLOR & 18MAY79 & 28NOV80 & 347 & 80 \\
\hline ZAPATA CORP & 18MAY79 & 23JAN81 & 289 & 88 \\
\hline ROWAN COMPANIES INC & 25MAY79 & 05DEC 80 & 261 & 80 \\
\hline N L INDUSTRIES & 08JUN79 & 04DEC81 & 274 & 130 \\
\hline PARADYNE CORP & 10AUG79 & 05JUN81 & 594 & 95 \\
\hline HANDY \& HARMAN & 24AUG79 & 22FEB80 & 111 & 26 \\
\hline KIRBY EXPLORATION INC & 26SEP79 & 07AUG81 & 1413 & 97 \\
\hline MITCHELL ENERGY \& DEV. & 16 NOV79 & 28NOV80 & 349 & 54 \\
\hline WARNER COMMUNICATIONS & 16NOV79 & 19FEB82 & 252 & 118 \\
\hline CHARTER MED CORP CL B CV & 30NOV79 & 12JUN81 & 539 & 80 \\
\hline VARCO INTL INC & 18APR80 & $19 \mathrm{DEC} 80$ & 297 & 35 \\
\hline SOUTHWEST AIRLINES CO & 16MAY80 & 05JUN81 & 269 & 55 \\
\hline CARLISLE CORPORATION & 23MAY80 & 24APR81 & 315 & 48 \\
\hline DANIEL INDUSTRIES INC & 06JUN80 & 05DEC80 & 119 & 26 \\
\hline BERGEN BRUNSWIG CL A & 13JUN80 & 10JUN83 & 453 & 156 \\
\hline BOWNE \& CO & 13JUN80 & 19JUN81 & 188 & 53 \\
\hline PANDICK INC & 13JUN80 & 24JUN83 & 917 & 158 \\
\hline PRIME COMPUTER INC & $20 J \mathrm{JN} 80$ & $05 J U N 81$ & 236 & 50 \\
\hline DOW JONES \& CO & 01AUG80 & 30SEP83 & 359 & 165 \\
\hline KEY PHARMACEUTICALS INC & 08AUG80 & 26AUG83 & 358 & 159 \\
\hline WHITEHALL CORP & 08AUG80 & 01JUL83 & 1126 & 151 \\
\hline M E I CORP & 20FEB81 & $10 \mathrm{DEC} 82$ & 226 & 94 \\
\hline DIEBOLD INC & $020 \mathrm{CT} 81$ & 22APR83 & 130 & 81 \\
\hline HOUSE OF FABRICS INC & 24NOV81 & $17 \mathrm{DEC} 82$ & 220 & 55 \\
\hline OXFORD INDUSTRIES INC & 25DEC 81 & $070 \mathrm{CT} 83$ & 339 & 93 \\
\hline TELECONCEPTS CORP & $12 \mathrm{FEB} 82$ & 01APR83 & 641 & 59 \\
\hline LIMITED INC & 19FEB82 & 01JUL83 & 674 & 71 \\
\hline DAYTON HUDSON CORP & 26FEB82 & 24JUN83 & 154 & 69 \\
\hline MERCANTILE STORES & 05MAR82 & 15JUL83 & 217 & 71 \\
\hline MACY R H \& CO & 19MAR82 & 24JUN83 & 202 & 66 \\
\hline SAGA CORP & 19MAR82 & 29JUL83 & 246 & 71 \\
\hline SMUCKER J M CO & 19MAR82 & 06MAY83 & 150 & 59 \\
\hline BLAIR JOHN \& COMPANY & 26MAR82 & 16SEP83 & 254 & 77 \\
\hline SUPERMARKETS GENERAL & 26MAR82 & 24JUN83 & 177 & 65 \\
\hline VARIAN ASSOCIATES INC & 02APR82 & 01JUL83 & 292 & 65 \\
\hline BROWN GROUP INC & 09APR82 & 08JUL83 & 158 & 65 \\
\hline ZAYRE CORP & 09APR82 & 29JUL83 & 288 & 68 \\
\hline STOP \& SHOP COMPANIES & 07MAY82 & $140 \mathrm{CT} 83$ & 518 & 75 \\
\hline
\end{tabular}


TABLE 1 - Continued

LISTING OF 222 STOCK MARKET WINNERS IN CHRONOLOGICAL ORDER OF HYPOTHETICAL BUY DATES

\begin{tabular}{|c|c|c|c|c|}
\hline Company & $\begin{array}{l}\text { Hypothetica } \\
\text { Buy Date }\end{array}$ & $\begin{array}{l}\text { ypothetica } \\
\text { Sell Date }\end{array}$ & Performance & $\begin{array}{c}\text { Weeks } \\
\text { Held }\end{array}$ \\
\hline DILLARD DEPT STORES CL A & 14MAY82 & $210 \mathrm{CT} 83$ & $227 \%$ & 75 \\
\hline V F CORP & 28MAY82 & 01JUL83 & 258 & 57 \\
\hline FLEETWOOD ENTERPRISES & 04JUN82 & 01JUL83 & 414 & 56 \\
\hline GIANT FOOD INC CL A & 04JUN82 & 29JUL83 & 191 & 60 \\
\hline E SYSTEMS INC & 25JUN82 & 01JUL83 & 175 & 53 \\
\hline WALGREEN COMPANY & 25JUN82 & $02 \mathrm{DEC} 83$ & 171 & 75 \\
\hline WATKINS-JOHNSON CO & 25JUN82 & 01JUL83 & 167 & 53 \\
\hline DUN \& BRADSTREET COS INC & 09JUL82 & 24JUN83 & 89 & 50 \\
\hline EDO CORPORATION & 09JUL82 & 08JUL83 & 273 & 52 \\
\hline INTL BUSINESS MACHINES & 09JUL82 & $210 \mathrm{CT} 83$ & 103 & 67 \\
\hline MARY KAY COSMETICS & 09JUL82 & 15APR83 & 212 & 40 \\
\hline PULTE HOME CORP & 23JUL82 & 24JUN83 & 644 & 48 \\
\hline CAROLINA FREIGHT CORP & $13 \mathrm{AUG} 82$ & $05 A U G 83$ & 289 & 51 \\
\hline FAMILY DOLLAR STORES & 13AUG82 & 15JUL83 & 323 & 48 \\
\hline MAGIC CHEF INC & 13AUG82 & 05AUG83 & 276 & 51 \\
\hline PAYLESS CASHWAYS INC & 13AUG82 & 08JUL83 & 184 & 47 \\
\hline SEARS ROEBUCK \& CO & 13AUG82 & 29JUL83 & 128 & 50 \\
\hline AYDIN CORP & 20AUG82 & 29JUL83 & 114 & 49 \\
\hline BANDAG INC & 20AUG82 & 10JUN83 & 109 & 42 \\
\hline CARTER-WALLACE INC & 20AUG82 & 13MAY83 & 128 & 38 \\
\hline COACHMEN INDUSTRIES INC & 20AUG82 & 01JUL83 & 469 & 45 \\
\hline COLLINS \& AIKMAN CORP & 20AUG82 & 08JUL83 & 210 & 46 \\
\hline CULLINET SOFTWARE INC & 20AUG82 & 10JUN83 & 205 & 42 \\
\hline DONNELLEY R R \& SONS & 20AUG82 & $060 \mathrm{CT} 83$ & 115 & 59 \\
\hline FINANCIAL CORP AMER & 20AUG82 & 29JUL83 & 290 & 49 \\
\hline FORD MOTOR OF CANADA & 20AUG82 & $280 \mathrm{CT} 83$ & 159 & 62 \\
\hline GENRAD INC & 20AUG82 & 30SEP83 & 190 & 58 \\
\hline HASBRO INC & 20AUG82 & $24 \mathrm{FEB} 84$ & 286 & 79 \\
\hline LOCKHEED CORP & 20AUG82 & $210 \mathrm{CT} 83$ & 119 & 61 \\
\hline LOWES COMPANIES INC & 20AUG82 & 08JUL83 & 148 & 46 \\
\hline MARION LABORATORIES INC & 20AUG82 & 17JUN83 & 182 & 43 \\
\hline MARRIOTT CORP & 20AUG82 & 01JUL83 & 95 & 45 \\
\hline N C R CORP & 20AUG82 & 02DEC83 & 130 & 67 \\
\hline OMNICARE INC & 20AUG82 & 20MAY83 & 141 & 39 \\
\hline RYLAND GROUP & 20AUG82 & 03JUN83 & 310 & 41 \\
\hline SERVICE CORPORATION INTL & 20AUG82 & 08JUL83 & 178 & 46 \\
\hline STANDARD MOTOR PROD CL A & 20AUG82 & 15JUL83 & 171 & 47 \\
\hline U S TOBACCO CO & 20AUG82 & $24 \mathrm{FEB} 84$ & 138 & 79 \\
\hline CHILTON CORP & 27AUG82 & 140CT83 & 494 & 59 \\
\hline
\end{tabular}


TABLE 1 - Continued

\section{LISTING OF 222 STOCK MARKET WINNERS IN CHRONOLOGICAL ORDER OF HYPOTHETICAL BUY DATES}

\section{Company}

CHRYSLER CORP

RUBBERMAID INC

STRIDE RITE CORP

TELEX CORP

U S SHOE CORP

CLOROX CO

AMES DEPARTMENT STORES

BOLT BERANEK \& NEWMAN

COLECO INDUSTRIES INC

HARTMARX CORP

LOGICON INC

HAZELTINE CORP

INTEGRATED RESOURCES

MERRILL LYNCH \& CO INC

OHIO MATTRESS CO DEL

T I E COMMUNICATIONS

JAMES RIVER CORP

NORTHERN TELECOM LTD

ROHM \& HAAS CO

TERADYNE INC

NATIONAL EDUCATION CORP

AMERICAN S\&L ASSOC FLA

FRUEHAUF CORP

GOLDEN NUGGET INC

AMREP CORPORATION

CIRCUIT CITY STORES INC

JAMESWAY CORPORATION
Hypothetical Hypothetical

Weeks

Buy Date Sell Date Performance Held

27AUG82
27AUG82
27AUG82
27AUG82
27AUG82
03SEP82
10SEP82
17SEP82
17SEP82
17SEP82
17SEP82
010CT82
010CT82
010CT82
010CT82
010CT82
080CT82
080CT82
150CT82
150CT82
220CT82
290CT82
24DEC82
24DEC82
31DEC82
21JAN83
18FEB83

01JUL83

22JUL83

01JUL83

10DEC82

01JUL83

24JUN83

09DEC83

29JUL83

$10 \mathrm{JUN} 83$

05AUG83

10JUN83

24JUN83

17JUN83

15JUL83

12AUG83

29JUL83

08JUL83

30 SEP 83

08JUL83

13JAN84

01JUL83

24JUN83

13JAN84

29JUL83

24FEB 84

$210 \mathrm{CT} 83$

070CT83
$279 \% \quad 44$

$134 \quad 47$

$187 \quad 44$

$137 \quad 15$

$198 \quad 44$

$124 \quad 42$

$222 \quad 65$

$328 \quad 45$

$561 \quad 38$

$106 \quad 46$

$132 \quad 38$

$194 \quad 38$

$246 \quad 37$

$184 \quad 41$

$214 \quad 45$

$221 \quad 43$

$177 \quad 39$

$159 \quad 51$

$125 \quad 38$

$258 \quad 65$

$297 \quad 36$

$317 \quad 34$

$105 \quad 55$

$155 \quad 31$

14260

$295 \quad 39$

$119 \quad 33$ 
TABLE 2

PRICE APPRECIATION AND LENGTH OF TIME POSITION HELD FOR THE 222 GREATEST STOCK MARKET WINNERS

\section{Panel A: Price Appreciation (in percent)}

\begin{tabular}{lrrrrr} 
& & \multicolumn{4}{c}{ Percentiles } \\
Mean & 349 & $5 \%$ & 104 & $95 \%$ & 945 \\
Median & 237 & $10 \%$ & 119 & $90 \%$ & 652 \\
& & $25 \%$ & 159 & $75 \%$ & 370
\end{tabular}

Panel B: Excess Price Appreciation Above S\&P 500 Return (in percent)

\begin{tabular}{lrrrrr}
\hline & & \multicolumn{4}{c}{ Percentiles } \\
Mean & 318 & $5 \%$ & 75 & $95 \%$ & 898 \\
Median & 209 & $10 \%$ & 96 & $90 \%$ & 607 \\
& & $25 \%$ & 126 & $75 \%$ & 347
\end{tabular}

Panel C: Elapsed Time Between Buy and Sell Dates (in weeks)

\begin{tabular}{lrrrrr} 
& & \multicolumn{4}{c}{ Percentiles } \\
Mean & 77 & $5 \%$ & 26 & $95 \%$ & 178 \\
Median & 60 & $10 \%$ & 34 & $90 \%$ & 155 \\
& & $25 \%$ & 44 & $75 \%$ & 96
\end{tabular}


TABLE 3

BANK HOLDINGS IN THE SELL, BUY, AND EIGHT PRECEDING QUARTERS

\begin{tabular}{|c|c|c|c|c|c|c|c|c|c|c|}
\hline \multirow[b]{2}{*}{ Quarter } & \multicolumn{10}{|c|}{ Percentile } \\
\hline & Mean & 1st & 5 th & 10 th & 25 th & 50th & 75th & 90 th & 95th & 99th \\
\hline SELL & 23.0 & 0 & 0 & 0 & 1.75 & 11 & 33.5 & 57.0 & 86.3 & 178 \\
\hline BUY & 12.3 & 0 & 0 & 0 & 0.00 & 3 & 13.2 & 35.7 & 48.7 & 17 \\
\hline BUY-1 & 10.6 & 0 & 0 & 0 & 0.00 & 3 & 11.0 & 29.7 & 42.4 & 170 \\
\hline BUY-2 & 98 & 0 & 0 & 0 & 0.00 & 2 & 10.0 & 27.7 & 38.8 & 16 \\
\hline BUY- & 10.0 & 0 & 0 & 0 & 0.00 & 2 & 10.0 & 26.8 & 37.3 & 181 \\
\hline BUY-4 & 10.3 & 0 & 0 & 0 & 0.00 & 3 & 11.0 & 27.0 & 39.0 & 19 \\
\hline BUY-5 & 10.0 & 0 & 0 & 0 & 0.00 & 2 & 10.0 & 25.2 & 38.0 & 19 \\
\hline UY-6 & 9.7 & 0 & 0 & 0 & 0.00 & 2 & 10.0 & 25.0 & 37.0 & 19 \\
\hline UY & 9.2 & 0 & 0 & 0 & 0.00 & 2 & 9.5 & 25.2 & 36.0 & 19 \\
\hline BUY-8 & 8.8 & 0 & 0 & 0 & 0.00 & 1 & 9.0 & 23.0 & 41.0 & 18 \\
\hline
\end{tabular}

Panel B: Percent of Outstanding Shares Held by Banks

Percentile

Quarter Mean 1st 5th 10th 25th 50th 75th 90th 95th 99th

$\begin{array}{lrlllllrrrr}\text { SELL } & 8.09 & 0 & 0 & 0 & 0.75 & 5.0 & 13.0 & 19.7 & 24.0 & 43.7 \\ \text { BUY } & 6.46 & 0 & 0 & 0 & 0.00 & 3.0 & 10.2 & 16.0 & 25.0 & 34.7 \\ \text { BUY-1 } & 6.24 & 0 & 0 & 0 & 0.00 & 3.0 & 10.0 & 17.0 & 23.8 & 34.0 \\ \text { BUY-2 } & 5.43 & 0 & 0 & 0 & 0.00 & 2.0 & 9.0 & 16.0 & 21.5 & 31.7 \\ \text { BUY-3 } & 5.42 & 0 & 0 & 0 & 0.00 & 2.0 & 9.0 & 16.0 & 20.6 & 31.7 \\ \text { BUY-4 } & 5.50 & 0 & 0 & 0 & 0.00 & 2.0 & 9.0 & 16.0 & 20.0 & 32.0 \\ \text { BUY-5 } & 5.35 & 0 & 0 & 0 & 0.00 & 2.0 & 9.0 & 16.0 & 22.2 & 31.0 \\ \text { BUY-6 } & 5.04 & 0 & 0 & 0 & 0.00 & 1.5 & 8.2 & 14.5 & 18.7 & 32.0 \\ \text { BUY-7 } & 5.06 & 0 & 0 & 0 & 0.00 & 1.0 & 8.0 & 15.6 & 19.3 & 33.1 \\ \text { BUY-8 } & 5.08 & 0 & 0 & 0 & 0.00 & 1.0 & 7.0 & 16.0 & 23.2 & 31.6\end{array}$


TABLE 4

MUTUAL FUND HOLDINGS IN THE SELL, BUY, AND EIGHT PRECEDING QUARTERS

\section{Panel A: Number of Mutual Funds Owning Shares}

\section{Percentile}

Quarter Mean 1st 5th 10th 25th 50th 75th 90th 95th 99th

$\begin{array}{lrllllrllll}\text { SELL } & 19.6 & 1 & 2 & 4 & 9 & 13 & 25 & 41.0 & 50.0 & 80.7 \\ \text { BUY } & 10.6 & 0 & 0 & 1 & 2 & 6 & 12 & 23.0 & 37.8 & 58.6 \\ \text { BUY-1 } & 8.6 & 0 & 0 & 0 & 1 & 4 & 11 & 19.7 & 30.5 & 49.7 \\ \text { BUY-2 } & 8.6 & 0 & 0 & 0 & 1 & 4 & 11 & 21.1 & 32.0 & 55.0 \\ \text { BUY-3 } & 9.1 & 0 & 0 & 0 & 1 & 4 & 11 & 23.6 & 29.6 & 57.0 \\ \text { BUY-4 } & 9.5 & 0 & 0 & 0 & 1 & 4 & 12 & 24.0 & 27.0 & 63.0 \\ \text { BUY-5 } & 9.7 & 0 & 0 & 0 & 1 & 4 & 13 & 22.2 & 27.2 & 74.0 \\ \text { BUY-6 } & 9.4 & 0 & 0 & 0 & 1 & 4 & 11 & 24.0 & 29.0 & 71.3 \\ \text { BUY-7 } & 9.0 & 0 & 0 & 0 & 1 & 3 & 10 & 24.0 & 30.3 & 70.1 \\ \text { BUY-8 } & 9.0 & 0 & 0 & 0 & 1 & 4 & 10 & 23.0 & 29.8 & 84.9\end{array}$

Panel B: Percent of Outstanding Stock Held by Mutual Funds

Percentile

Quarter Mean 1st 5th 10th 25th 50th 75th 90th 95th 99th

$\begin{array}{lllllllrlll}\text { SELL } & 7.88 & 0 & 1 & 1 & 3 & 6 & 11.0 & 16.0 & 18.0 & 39.3 \\ \text { BUY } & 4.91 & 0 & 0 & 0 & 1 & 3 & 8.0 & 12.0 & 14.0 & 22.5 \\ \text { BUY-1 } & 4.37 & 0 & 0 & 0 & 0 & 3 & 7.0 & 11.0 & 13.8 & 23.0 \\ \text { BUY-2 } & 4.14 & 0 & 0 & 0 & 0 & 3 & 7.0 & 10.0 & 13.8 & 22.8 \\ \text { BUY-3 } & 4.22 & 0 & 0 & 0 & 0 & 2 & 7.0 & 11.0 & 13.3 & 22.4 \\ \text { BUY-4 } & 4.44 & 0 & 0 & 0 & 0 & 3 & 7.0 & 12.0 & 15.0 & 19.0 \\ \text { BUY-5 } & 4.56 & 0 & 0 & 0 & 0 & 3 & 7.0 & 11.0 & 16.1 & 24.2 \\ \text { BUY-6 } & 4.25 & 0 & 0 & 0 & 0 & 3 & 6.0 & 11.0 & 16.0 & 23.0 \\ \text { BUY-7 } & 4.35 & 0 & 0 & 0 & 0 & 2 & 6.5 & 11.0 & 17.3 & 24.1 \\ \text { BUY-8 } & 4.56 & 0 & 0 & 0 & 0 & 2 & 7.0 & 13.0 & 18.6 & 24.2\end{array}$


TABLE 5

INVESTMENT ADVISOR HOLDINGS IN THE SELL, BUY, AND EIGHT PRECEDING QUARTERS

\section{Panel A: Number of Investment Advisors Owning Shares}

\section{Percentile}

Quarter Mean 1st 5th 10th 25th 50th 75th 90th 95th 99th

$\begin{array}{lllllllllll}\text { SELL } & 20.9 & 0 & 0 & 0 & 0 & 14 & 31.0 & 47.0 & 74.5 & 125\end{array}$

$\begin{array}{lllllllllll}\text { BUY } & 9.3 & 0 & 0 & 0 & 0 & 0 & 13.0 & 26.4 & 35.8 & 110\end{array}$

$\begin{array}{lllllllllll}\text { BUY-1 } & 7.7 & 0 & 0 & 0 & 0 & 0 & 9.0 & 23.7 & 30.8 & 100\end{array}$

$\begin{array}{lllllllllll}\text { BUY-2 } & 7.2 & 0 & 0 & 0 & 0 & 0 & 8.2 & 22.7 & 30.8 & 96\end{array}$

$\begin{array}{lllllllllll}\text { BUY-3 } & 7.2 & 0 & 0 & 0 & 0 & 0 & 7.0 & 21.0 & 31.8 & 105\end{array}$

$\begin{array}{lllllllllll}\text { BUY-4 } & 7.4 & 0 & 0 & 0 & 0 & 0 & 7.0 & 21.0 & 36.0 & 107\end{array}$

$\begin{array}{lllllllllll}\text { BUY-5 } & 7.2 & 0 & 0 & 0 & 0 & 0 & 6.5 & 20.4 & 34.2 & 110\end{array}$

$\begin{array}{lllllllllll}\text { BUY-6 } & 7.1 & 0 & 0 & 0 & 0 & 0 & 6.0 & 20.5 & 30.7 & 117\end{array}$

$\begin{array}{lllllllllll}\text { BUY-7 } & 6.7 & 0 & 0 & 0 & 0 & 0 & 5.0 & 22.0 & 27.5 & 115\end{array}$

$\begin{array}{lllllllllll}\text { BUY-8 } & 6.4 & 0 & 0 & 0 & 0 & 0 & 4.0 & 22.0 & 28.2 & 121\end{array}$

Panel B: Percent of Outstanding Stocks Held by Investment Advisors

Percentile

Quarter Mean 1st 5th 10th 25th 50th 75th 90th 95th 99th

$\begin{array}{lllllllllll}\text { SELL } & 14.9 & 0 & 0 & 0 & 0 & 10.5 & 25.0 & 36.0 & 40.7 & 82.3\end{array}$

$\begin{array}{lllllllllll}\text { BUY } & 7.2 & 0 & 0 & 0 & 0 & 0.0 & 13.0 & 23.0 & 31.8 & 58.1\end{array}$

$\begin{array}{lllllllllll}\text { BUY-1 } & 6.3 & 0 & 0 & 0 & 0 & 0.0 & 10.2 & 20.7 & 31.5 & 58.0\end{array}$

$\begin{array}{lllllllllll}\text { BUY-2 } & 5.8 & 0 & 0 & 0 & 0 & 0.0 & 9.2 & 21.0 & 27.8 & 44.0\end{array}$

$\begin{array}{lllllllllll}\text { BUY-3 } & 5.4 & 0 & 0 & 0 & 0 & 0.0 & 8.5 & 21.6 & 26.3 & 36.0\end{array}$

$\begin{array}{lllllllllll}\text { BUY-4 } & 5.4 & 0 & 0 & 0 & 0 & 0.0 & 8.0 & 20.0 & 27.0 & 37.0\end{array}$

$\begin{array}{lllllllllll}\text { BUY-5 } & 5.2 & 0 & 0 & 0 & 0 & 0.0 & 7.0 & 20.2 & 29.1 & 38.0\end{array}$

$\begin{array}{lllllllllll}\text { BUY-6 } & 5.3 & 0 & 0 & 0 & 0 & 0.0 & 8.0 & 22.5 & 27.0 & 34.1\end{array}$

$\begin{array}{lllllllllll}\text { BUY-7 } & 5.0 & 0 & 0 & 0 & 0 & 0.0 & 6.5 & 21.0 & 24.6 & 35.1\end{array}$

$\begin{array}{lllllllllll}\text { BUY-8 } & 4.8 & 0 & 0 & 0 & 0 & 0.0 & 7.0 & 19.0 & 25.6 & 36.2\end{array}$


TABLE 6

INSURANCE COMPANY HOLDINGS IN THE SELL, BUY, AND EIGHT PRECEDING QUARTERS

Panel A: Number of Insurance Companies Owning Shares

Percentile

Quarter Mean 1st 5th 10th 25th 50th 75th 90th 95th 99th

$\begin{array}{lllllllllll}\text { SELL } & 4.36 & 0 & 0 & 0 & 0 & 2 & 7.0 & 11.0 & 15.7 & 23.5\end{array}$

$\begin{array}{lllllllllll}\text { BUY } & 2.80 & 0 & 0 & 0 & 0 & 0 & 4.0 & 8.0 & 11.0 & 34.7\end{array}$

$\begin{array}{lllllllllll}\text { BUY-1 } & 2.28 & 0 & 0 & 0 & 0 & 0 & 3.0 & 6.7 & 11.8 & 21.3\end{array}$

$\begin{array}{lllllllllll}\text { BUY-2 } & 1.90 & 0 & 0 & 0 & 0 & 0 & 2.0 & 6.0 & 8.0 & 20.3\end{array}$

$\begin{array}{lllllllllll}\text { BUY-3 } & 1.94 & 0 & 0 & 0 & 0 & 0 & 1.5 & 6.0 & 8.6 & 22.7\end{array}$

$\begin{array}{lllllllllll}\text { BUY-4 } & 2.38 & 0 & 0 & 0 & 0 & 0 & 2.0 & 7.0 & 10.0 & 38.0\end{array}$

$\begin{array}{lllllllllll}\text { BUY-5 } & 2.15 & 0 & 0 & 0 & 0 & 0 & 2.0 & 7.0 & 9.0 & 24.7\end{array}$

$\begin{array}{lllllllllll}\text { BUY-6 } & 2.08 & 0 & 0 & 0 & 0 & 0 & 2.0 & 7.0 & 8.5 & 28.8\end{array}$

$\begin{array}{lllllllllll}\text { BUY-7 } & 1.89 & 0 & 0 & 0 & 0 & 0 & 1.0 & 6.0 & 8.3 & 30.0\end{array}$

$\begin{array}{lllllllllll}\text { BUY-8 } & 2.35 & 0 & 0 & 0 & 0 & 0 & 2.0 & 7.2 & 10.0 & 38.4\end{array}$

Panel B: Percent of Outstanding Stocks Held by

Insurance Companies

Percentile

Quarter Mean 1st 5th 10th 25th 50th 75th 90th 95th 99th

$\begin{array}{lllllllllll}\text { SELL } & 2.61 & 0 & 0 & 0 & 0 & 1 & 4 & 8.0 & 10.0 & 14.5\end{array}$

$\begin{array}{lllllllllll}\text { BUY } & 1.94 & 0 & 0 & 0 & 0 & 0 & 3 & 7.0 & 8.0 & 15.5\end{array}$

$\begin{array}{lllllllllll}\text { BUY-1 } & 1.58 & 0 & 0 & 0 & 0 & 0 & 2 & 6.0 & 8.0 & 14.5\end{array}$

$\begin{array}{lllllllllll}\text { BUY-2 } & 1.47 & 0 & 0 & 0 & 0 & 0 & 2 & 5.7 & 8.0 & 13.3\end{array}$

$\begin{array}{lllllllllll}\text { BUY-3 } & 1.38 & 0 & 0 & 0 & 0 & 0 & 1 & 6.0 & 7.3 & 11.8\end{array}$

$\begin{array}{lllllllllll}\text { BUY-4 } & 1.45 & 0 & 0 & 0 & 0 & 0 & 2 & 6.0 & 8.0 & 11.0\end{array}$

$\begin{array}{lllllllllll}\text { BUY-5 } & 1.29 & 0 & 0 & 0 & 0 & 0 & 1 & 5.0 & 7.0 & 10.0\end{array}$

$\begin{array}{lllllllllll}\text { BUY-6 } & 1.24 & 0 & 0 & 0 & 0 & 0 & 1 & 5.0 & 7.0 & 13.0\end{array}$

$\begin{array}{lllllllllll}\text { BUY-7 } & 1.06 & 0 & 0 & 0 & 0 & 0 & 1 & 4.0 & 6.3 & 13.0\end{array}$

$\begin{array}{lllllllllll}\text { BUY-8 } & 1.27 & 0 & 0 & 0 & 0 & 0 & 1 & 4.0 & 7.0 & 14.8\end{array}$ 
TABLE 7

CORPORATE INSIDER TRANSACTIONS AMONG THE

222 GREATEST WINNERS IN THE SELL, BUY, AND EIGHT PRECEDING QUARTERS

Panel A: Number of Insiders Buying Stock

Percentile

Quarter Mean 1st 5th 10th 25th 50th 75th 90th 95th 99th

$\begin{array}{lllllllllll}\text { SELL } & 0.44 & 0 & 0 & 0 & 0 & 0 & 1 & 2 & 2.84 & 3.77\end{array}$

$\begin{array}{lllllllllll}\text { BUY } & 0.37 & 0 & 0 & 0 & 0 & 0 & 1 & 1 & 2.00 & 3.77\end{array}$

$\begin{array}{lllllllllll}\text { BUY-1 } & 0.31 & 0 & 0 & 0 & 0 & 0 & 0 & 1 & 2.00 & 3.00\end{array}$

$\begin{array}{lllllllllll}\text { BUY-2 } & 0.35 & 0 & 0 & 0 & 0 & 0 & 0 & 1 & 2.00 & 4.00\end{array}$

$\begin{array}{lllllllllll}\text { BUY-3 } & 0.21 & 0 & 0 & 0 & 0 & 0 & 0 & 1 & 1.00 & 2.86\end{array}$

$\begin{array}{lllllllllll}\text { BUY-4 } & 0.32 & 0 & 0 & 0 & 0 & 0 & 1 & 1 & 2.00 & 3.00\end{array}$

$\begin{array}{lllllllllll}\text { BUY-5 } & 0.30 & 0 & 0 & 0 & 0 & 0 & 0 & 1 & 2.00 & 3.02\end{array}$

$\begin{array}{lllllllllll}\text { BUY-6 } & 0.21 & 0 & 0 & 0 & 0 & 0 & 0 & 1 & 1.00 & 2.15\end{array}$

$\begin{array}{lllllllllll}\text { BUY-7 } & 0.29 & 0 & 0 & 0 & 0 & 0 & 0 & 1 & 2.00 & 4.00\end{array}$

$\begin{array}{lllllllllll}\text { BUY-8 } & 0.29 & 0 & 0 & 0 & 0 & 0 & 0 & 1 & 1.00 & 3.12\end{array}$

Panel B: Number of Insiders Selling Stock

Percentile

Quarter Mean 1st 5th 10th 25th 50th 75th 90th 95th 99th

$\begin{array}{lllllllllll}\text { SELL } & 1.80 & 0 & 0 & 0 & 0 & 1 & 3 & 5 & 6 & 10\end{array}$

$\begin{array}{lllllllllll}\text { BUY } & 1.38 & 0 & 0 & 0 & 0 & 1 & 2 & 4 & 5 & 8\end{array}$

$\begin{array}{lllllllllll}\text { BUY-1 } & 0.84 & 0 & 0 & 0 & 0 & 0 & 1 & 3 & 4 & 9\end{array}$

$\begin{array}{lllllllllll}\text { BUY-2 } & 0.72 & 0 & 0 & 0 & 0 & 0 & 1 & 3 & 4 & 6\end{array}$

$\begin{array}{lllllllllll}\text { BUY-3 } & 0.80 & 0 & 0 & 0 & 0 & 0 & 1 & 2 & 4 & 7\end{array}$

$\begin{array}{lllllllllll}\text { BUY-4 } & 0.68 & 0 & 0 & 0 & 0 & 0 & 1 & 2 & 3 & 5\end{array}$

$\begin{array}{lllllllllll}\text { BUY-5 } & 0.75 & 0 & 0 & 0 & 0 & 0 & 1 & 2 & 4 & 9\end{array}$

$\begin{array}{lllllllllll}\text { BUY-6 } & 0.67 & 0 & 0 & 0 & 0 & 0 & 1 & 2 & 4 & 6\end{array}$

$\begin{array}{lllllllllll}\text { BUY-7 } & 0.78 & 0 & 0 & 0 & 0 & 0 & 1 & 3 & 4 & 7\end{array}$

$\begin{array}{lllllllllll}\text { BUY-8 } & 0.69 & 0 & 0 & 0 & 0 & 0 & 1 & 3 & 3 & 7\end{array}$


TABLE 8

PRICE/BOOK AND PRICE-EARNINGS RATIOS AMONG

THE 222 GREATEST WINNERS IN THE SELL, BUY, AND EIGHT PRECEDING QUARTERS

\section{Panel A: Price/Book Ratios}

Percentile

Quarter Mean 1st 5th 10th 25th 50th 75th 90th 95th 99th

$\begin{array}{lllllllllll}\text { SELL } & 2.64 & 0.17 & 0.33 & 0.42 & 1.15 & 2.24 & 3.43 & 4.95 & 6.49 & 11.26\end{array}$

$\begin{array}{lllllllllll}\text { BUY } & 0.95 & 0.07 & 0.12 & 0.20 & 0.31 & 0.60 & 1.10 & 2.14 & 2.74 & 6.92\end{array}$

$\begin{array}{lllllllllll}\text { BUY-1 } & 0.69 & 0.04 & 0.08 & 0.14 & 0.26 & 0.45 & 0.80 & 1.52 & 1.94 & 5.28\end{array}$

$\begin{array}{lllllllllll}\text { BUY-2 } & 0.62 & 0.04 & 0.08 & 0.13 & 0.26 & 0.40 & 0.68 & 1.39 & 1.86 & 4.74\end{array}$

$\begin{array}{lllllllllll}\text { BUY-3 } & 0.58 & 0.04 & 0.07 & 0.11 & 0.22 & 0.41 & 0.66 & 1.33 & 1.89 & 4.75\end{array}$

$\begin{array}{lllllllllll}\text { BUY-4 } & 0.49 & 0.05 & 0.07 & 0.11 & 0.18 & 0.40 & 0.60 & 1.10 & 1.41 & 2.83\end{array}$

$\begin{array}{lllllllllll}\text { BUY-5 } & 0.52 & 0.05 & 0.07 & 0.10 & 0.20 & 0.38 & 0.61 & 1.06 & 1.58 & 3.19\end{array}$

$\begin{array}{lllllllllll}\text { BUY-6 } & 0.50 & 0.05 & 0.07 & 0.10 & 0.18 & 0.38 & 0.63 & 1.03 & 1.71 & 2.82\end{array}$

$\begin{array}{lllllllllll}\text { BUY-7 } & 0.49 & 0.05 & 0.06 & 0.09 & 0.18 & 0.34 & 0.57 & 0.95 & 1.55 & 3.35\end{array}$

$\begin{array}{lllllllllll}\text { BUY-8 } & 0.45 & 0.04 & 0.07 & 0.09 & 0.18 & 0.29 & 0.50 & 0.96 & 1.46 & 2.52\end{array}$

\section{Panel B: Price-Earnings Ratios}

Percentile

Quarter Mean 1st 5th 10th 25th 50th 75th 90th 95th 99th

$\begin{array}{lllllllllll}\text { SELL } & 29.4 & 7.0 & 9.0 & 11.0 & 16.5 & 24.0 & 37.0 & 59.0 & 71.1 & 92.1\end{array}$

$\begin{array}{lllllllllll}\text { BUY } & 13.6 & 2.0 & 4.0 & 5.0 & 7.0 & 10.0 & 14.0 & 20.0 & 27.8 & 119.7\end{array}$

$\begin{array}{lllllllllll}\text { BUY-1 } & 11.7 & 2.0 & 4.0 & 5.0 & 6.0 & 8.0 & 12.0 & 18.0 & 23.0 & 152.0\end{array}$

$\begin{array}{lllllllllll}\text { BUY-2 } & 10.8 & 1.9 & 4.0 & 5.0 & 6.0 & 9.0 & 13.0 & 17.0 & 21.0 & 36.3\end{array}$

$\begin{array}{lllllllllll}\text { BUY-3 } & 10.9 & 1.9 & 5.0 & 5.0 & 6.0 & 9.0 & 13.0 & 18.0 & 23.4 & 48.6\end{array}$

$\begin{array}{lllllllllll}\text { BUY-4 } & 11.1 & 1.9 & 5.0 & 5.0 & 6.0 & 8.0 & 13.0 & 18.0 & 27.1 & 68.0\end{array}$

$\begin{array}{lllllllllll}\text { BUY-5 } & 12.1 & 2.0 & 4.6 & 5.0 & 7.0 & 9.0 & 13.0 & 21.0 & 34.0 & 66.7\end{array}$

$\begin{array}{lllllllllll}\text { BUY-6 } & 12.5 & 2.0 & 4.0 & 5.0 & 7.0 & 9.0 & 14.0 & 21.0 & 26.4 & 100.0\end{array}$

$\begin{array}{lllllllllll}\text { BUY-7 } & 11.7 & 2.0 & 4.0 & 5.0 & 7.0 & 9.0 & 14.0 & 21.0 & 27.5 & 59.0\end{array}$

$\begin{array}{lllllllllll}\text { BUY-8 } & 11.7 & 2.0 & 4.0 & 5.0 & 6.0 & 9.0 & 14.0 & 19.2 & 25.6 & 76.2\end{array}$ 
TABLE 9

\section{SHARE PRICES, MARKET CAPITALIZATIONS, AND BETAS OF THE 222 GREATEST WINNERS}

Panel A: Share Prices on the Buy Date (in \$)

\begin{tabular}{lrrrrr} 
& & \multicolumn{4}{c}{ Percentiles } \\
Mean & 27.69 & $5 \%$ & 10.71 & $95 \%$ & 58.59 \\
Median & 24.07 & $10 \%$ & 12.80 & $90 \%$ & 49.70 \\
& & $25 \%$ & 17.32 & $75 \%$ & 32.81
\end{tabular}

Panel B: Stock Market Capitalization on Buy Date (in \$ million)

\begin{tabular}{lrrrrr} 
& & \multicolumn{4}{c}{ Percentiles } \\
Mean & 484.3 & $5 \%$ & 19.3 & $95 \%$ & $1,375.5$ \\
Median & 120.1 & $10 \%$ & 30.9 & $90 \%$ & 802.9 \\
& & $25 \%$ & 53.9 & $75 \%$ & 316.4
\end{tabular}

Note: Stock market capitalizations are defined as price per share times number of shares outstanding.

\section{Panel C: Stock Betas}

\begin{tabular}{llrrrr} 
& & \multicolumn{4}{c}{ Percentiles } \\
Mean & 1.14 & $5 \%$ & 0.41 & $95 \%$ & 1.97 \\
Median & 1.14 & $10 \%$ & 0.52 & $90 \%$ & 1.78 \\
& & $25 \%$ & 0.79 & $75 \%$ & 1.46
\end{tabular}

Note: Betas are calculated by using weekly returns during the period 2 years prior to the buy date. The proxy for the market portfolio is a valueweighted index of all New York and American Stock Exchange companies. 
TABLE 10

RELATIVE STRENGTH RANKS AND DATAGRAPH RATINGS OF THE 222 GREATEST WINNERS IN THE SELL, BUY, AND EIGHT PRECEDING QUARTERS

\begin{tabular}{|c|c|c|c|c|c|c|c|c|c|c|}
\hline \multicolumn{11}{|c|}{ Panel A: Relative Strength Ranks (99= Highest, $1=$ Lowest) } \\
\hline \multirow[b]{2}{*}{ Quarter } & \multicolumn{10}{|c|}{ Percentile } \\
\hline & Mean & lst & 5 th & 10 th & 25th & 50 th & 75 th & 90th & 95th & 99 th \\
\hline SELL & 74.0 & 5.2 & 20.0 & 37.0 & 62.0 & 82.0 & 93.0 & 97.0 & 98.0 & 99.0 \\
\hline BUY & 90.2 & 52.1 & 72.0 & 78.0 & 87.0 & 93.0 & 97.0 & 99.0 & 99.0 & 99.0 \\
\hline BUY-1 & 78.1 & 21.6 & 45.0 & 50.0 & 69.0 & 81.0 & 92.0 & 96.0 & 98.0 & 99.0 \\
\hline BUY-2 & 70.0 & 6.7 & 23.0 & 32.9 & 56.0 & 78.0 & 90.0 & 96.0 & 98.0 & 99.0 \\
\hline BUY-3 & 64.4 & 1.1 & 11.0 & 17.0 & 48.0 & 69.0 & 87.0 & 94.0 & 98.0 & 99.0 \\
\hline BUY-4 & 57.9 & 1.0 & 11.0 & 18.0 & 37.0 & 61.0 & 82.0 & 92.0 & 96.0 & 98.0 \\
\hline BUY-5 & 58.4 & 3.7 & 9.0 & 16.0 & 35.5 & 63.0 & 83.5 & 94.0 & 96.5 & 98.1 \\
\hline BUY-6 & 60.6 & 4.4 & 10.0 & 16.0 & 40.0 & 63.0 & 86.0 & 95.0 & 97.0 & 99.0 \\
\hline BUY-7 & 58.6 & 1.0 & 8.2 & 15.0 & 37.0 & 61.5 & 83.7 & 93.0 & 98.0 & 99.0 \\
\hline BUY-8 & 60.8 & 1.8 & 9.0 & 17.1 & 39.0 & 65.5 & 84.0 & 95.0 & 97.0 & 99.0 \\
\hline
\end{tabular}

Panel B: Datagraph Ratings $(99=$ Highest, $1=$ Lowest $)$

Percentile

Quarter Mean 1st 5th 10th 25th 50th 75th 90th 95th 99th

$\begin{array}{lllllllllll}\text { SELL } & 72.2 & 40.3 & 50.1 & 55.0 & 64.0 & 73.0 & 81.5 & 88.0 & 91.0 & 96.7\end{array}$

$\begin{array}{llllllllllll}\text { BUY } & 78.3 & 1.2 & 60.0 & 64.0 & 73.0 & 80.0 & 87.0 & 93.0 & 96.0 & 99.0\end{array}$

$\begin{array}{llllllllllll}\text { BUY-1 } & 67.4 & 1.4 & 45.0 & 51.0 & 58.0 & 70.0 & 77.0 & 85.0 & 89.0 & 97.0\end{array}$

$\begin{array}{lllllllllll}\text { BUY-2 } & 63.9 & 23.4 & 37.0 & 43.0 & 54.0 & 66.0 & 75.0 & 84.0 & 86.0 & 94.8\end{array}$

$\begin{array}{lllllllllll}\text { BUY-3 } & 61.8 & 20.1 & 29.0 & 37.0 & 50.0 & 63.0 & 76.0 & 83.0 & 90.5 & 96.9\end{array}$

$\begin{array}{lllllllllll}\text { BUY-4 } & 57.7 & 10.6 & 29.8 & 35.0 & 46.0 & 59.0 & 70.0 & 77.0 & 83.0 & 94.1\end{array}$

$\begin{array}{lllllllllll}\text { BUY-5 } & 59.9 & 21.8 & 34.0 & 38.0 & 49.0 & 59.0 & 71.0 & 83.2 & 88.6 & 97.1\end{array}$

$\begin{array}{lllllllllll}\text { BUY-6 } & 60.9 & 10.6 & 29.0 & 37.0 & 49.0 & 63.0 & 74.0 & 85.0 & 92.2 & 97.0\end{array}$

$\begin{array}{lllllllllll}\text { BUY-7 } & 58.4 & 16.8 & 26.2 & 34.0 & 46.0 & 58.5 & 71.0 & 84.5 & 89.0 & 96.3\end{array}$

$\begin{array}{lllllllllll}\text { BUY-8 } & 56.9 & 1.0 & 24.1 & 33.0 & 43.2 & 58.0 & 70.7 & 81.0 & 85.0 & 94.5\end{array}$ 
TABLE 11

INDUSTRY GROUP RANKS OF THE 222 GREATEST WINNERS

IN THE SELL, BUY, AND EIGHT PRECEDING QUARTERS

Panel A: Industry Group Rank $(1=$ Highest $)$

Percentile

Quarter Mean 1st 5th 10th 25th 50th 75th 90th 95th 99th

$\begin{array}{lllllllllll}\text { SELL } & 81 & 1 & 5 & 12 & 33 & 72 & 130 & 167 & 173 & 197\end{array}$

$\begin{array}{lllllllllll}\text { BUY } & 54 & 1 & 3 & 7 & 19 & 43 & 82 & 115 & 145 & 177\end{array}$

$\begin{array}{lllllllllll}\text { BUY-1 } & 72 & 2 & 6 & 16 & 39 & 65 & 101 & 139 & 157 & 179\end{array}$

$\begin{array}{lllllllllll}\text { BUY-2 } & 81 & 1 & 7 & 16 & 37 & 74 & 128 & 158 & 171 & 186\end{array}$

$\begin{array}{llllllllllll}\text { BUY-3 } & 88 & 2 & 7 & 16 & 42 & 81 & 133 & 176 & 186 & 223\end{array}$

$\begin{array}{lllllllllll}\text { BUY-4 } & 91 & 1 & 8 & 24 & 45 & 87 & 140 & 169 & 180 & 190\end{array}$

$\begin{array}{lllllllllll}\text { BUY-5 } & 94 & 3 & 10 & 15 & 42 & 92 & 151 & 175 & 180 & 198\end{array}$

$\begin{array}{lllllllllll}\text { BUY-6 } & 89 & 2 & 7 & 18 & 45 & 80 & 132 & 176 & 180 & 193\end{array}$

$\begin{array}{lllllllllll}\text { BUY-7 } & 92 & 3 & 8 & 14 & 42 & 91 & 137 & 175 & 183 & 234\end{array}$

$\begin{array}{lllllllllll}\text { BUY-8 } & 96 & 1 & 9 & 16 & 50 & 98 & 145 & 176 & 188 & 196\end{array}$ 


\section{TABLE 12}

PRETAX PROFIT MARGINS AND CHANGES IN QUARTERLY EARNINGS AMONG THE 222 GREATEST WINNERS IN THE SELL, BUY, AND EIGHT PRECEDING QUARTERS

\section{Panel A: Pretax Profit Margins (in percent)}

Percentile

Quarter Mean 1st 5th 10th 25th 50th 75th 90th 95th 99th

$\begin{array}{lrrrrrrrrrr}\text { SELL } & 14.5 & -3.2 & 3.7 & 5.7 & 8.2 & 13.0 & 18.5 & 26.4 & 33.0 & 46.3 \\ \text { BUY } & 12.7 & -3.5 & 2.9 & 4.0 & 7.0 & 11.2 & 16.2 & 23.5 & 28.2 & 39.6 \\ \text { BUY-1 } & 12.3 & -6.0 & 2.2 & 3.5 & 6.5 & 10.8 & 15.7 & 24.5 & 30.6 & 45.0 \\ \text { BUY-2 } & 12.0 & -6.0 & 2.0 & 3.4 & 6.1 & 10.5 & 15.3 & 23.9 & 32.1 & 45.4 \\ \text { BUY-3 } & 11.1 & -6.4 & 1.6 & 2.4 & 5.5 & 10.0 & 14.8 & 21.6 & 28.4 & 38.6 \\ \text { BUY-4 } & 10.2 & -6.9 & 1.4 & 2.2 & 4.9 & 9.3 & 13.5 & 20.8 & 26.7 & 37.9 \\ \text { BUY-5 } & 9.7 & -14.5 & 0.5 & 1.8 & 4.4 & 8.5 & 12.7 & 19.8 & 24.8 & 38.1 \\ \text { BUY-6 } & 9.8 & -6.0 & 0.6 & 1.9 & 4.3 & 8.3 & 12.5 & 20.1 & 28.4 & 40.6 \\ \text { BUY-7 } & 9.0 & -24.2 & 0.4 & 1.8 & 4.1 & 8.2 & 12.2 & 18.9 & 24.9 & 40.7 \\ \text { BUY-8 } & 8.4 & -24.4 & -3.1 & 1.8 & 4.1 & 7.8 & 11.9 & 17.7 & 25.1 & 40.9\end{array}$

Panel B: Changes in Quarterly Earnings (percentages)

Percentile

\begin{tabular}{|c|c|c|c|c|c|c|c|c|c|c|}
\hline Quarter & Mean & 1st & 5 th & 10 th & 25 th & 50 th & 75th & 90 th & 95th & 99 th \\
\hline SELL & 16.9 & -70 & -44 & -32 & -10 & 8.05 & 29.4 & 66 & 113 & 262 \\
\hline BUY & 45.9 & -82 & -41 & -26 & 0 & 7.40 & 39.0 & 103 & 179 & 1747 \\
\hline BUY-1 & 60.8 & -63 & -42 & -22 & 0 & 14.10 & 41.7 & 108 & 232 & 1731 \\
\hline BUY-2 & 50.4 & -91 & -60 & -33 & -4 & 3.00 & 35.7 & 100 & 241 & 1158 \\
\hline BUY-3 & 22.6 & -90 & -50 & -40 & -3 & 0.00 & 33.3 & 100 & 150 & 500 \\
\hline BUY-4 & 29.0 & -97 & -73 & -45 & -11 & 0.00 & 34.3 & 100 & 180 & 867 \\
\hline BUY-5 & 32.7 & -92 & -54 & -37 & -14 & 0.00 & 43.1 & 137 & 221 & 603 \\
\hline BUY-6 & 41.5 & -276 & -76 & -50 & -16 & 0.00 & 30.4 & 97 & 147 & 1925 \\
\hline BUY-7 & 19.2 & -700 & -81 & -53 & -7 & 1.90 & 42.3 & 100 & 194 & 484 \\
\hline BUY-8 & 35.8 & -326 & -59 & -37 & -10 & 4.00 & 40.0 & 131 & 257 & 828 \\
\hline
\end{tabular}


TABLE 13

FIVE-YEAR EARNINGS GROWTH RATES AND QUARTERLY CHANGES IN SALES FOR THE 222 GREATEST WINNERS IN THE SELL, BUY, AND EIGHT PRECEDING QUARTERS

Panel A: Changes in Quarterly Sales (percentages)

Percentile

\begin{tabular}{|c|c|c|c|c|c|c|c|c|c|c|}
\hline uarte & Mean & 1st & 5 th & 10th & 25 th & 50 th & 75th & 90th & 95th & 99th \\
\hline ELL & 8.4 & -29 & -21 & -9 & -1.5 & 7.10 & 14.8 & 29.7 & 40.4 & 96.8 \\
\hline $\mathrm{x}$ & 9.5 & -48 & -22 & -10 & -1.4 & 7.30 & 16.0 & 32.9 & 40.4 & 93.9 \\
\hline $3 U Y$ & 11.8 & -35 & -14 & -7 & 0.2 & 9.25 & 16.0 & 30.6 & 54.2 & 153.1 \\
\hline BUY-2 & 6.7 & -30 & -25 & -17 & -2.7 & 5.20 & 14.0 & 25.2 & 34.8 & 114.1 \\
\hline BUY-3 & 8.5 & -47 & -31 & -15 & -4.3 & 6.00 & 16.3 & 30.9 & 44.1 & 99.7 \\
\hline BUY-4 & 7.1 & -74 & -29 & -13 & -3.7 & 4.40 & 15.5 & 27.5 & 40.7 & 158.8 \\
\hline B) & 9. & -29 & -15 & -9 & -1.2 & 5.60 & 15.7 & 32.6 & 49.1 & 86.5 \\
\hline BUY-6 & 3.9 & -36 & -24 & -18 & -4.7 & 4.30 & 12.0 & 22.1 & 29.2 & 57.9 \\
\hline BUY-7 & 7.0 & -52 & -32 & -17 & -4.4 & 4.20 & 14.4 & 31.2 & 51.8 & 144.5 \\
\hline BUY-8 & 10.7 & -41 & -19 & -7 & 0.0 & 9.30 & 18.9 & 34.6 & 45.2 & 95.3 \\
\hline
\end{tabular}

Panel B: Five-year Earnings Growth Rates (in percent, annualized)

Percentile

Quarter Mean 1st 5th 10th 25th 50th 75 th 90th 95th 99 th

$\begin{array}{lllllllllll}\text { SELL } & 38.2 & -14.0 & 3.3 & 10.6 & 18.0 & 30.0 & 48.5 & 83.8 & 98.1 & 156\end{array}$

$\begin{array}{lllllllllll}\text { BUY } & 23.0 & -22.5 & -10.5 & -4.0 & 8.5 & 17.0 & 31.0 & 55.0 & 70.5 & 131\end{array}$

$\begin{array}{lllllllllll}\text { BUY-1 } & 21.6 & -24.5 & -10.7 & -5.0 & 7.0 & 16.0 & 29.5 & 54.0 & 70.2 & 128\end{array}$

$\begin{array}{lllllllllll}\text { BUY-2 } & 21.4 & -28.6 & -13.0 & -6.2 & 6.0 & 16.0 & 30.0 & 52.2 & 71.6 & 137\end{array}$

$\begin{array}{lllllllllll}\text { BUY-3 } & 20.1 & -29.2 & -13.0 & -7.0 & 4.0 & 16.0 & 29.0 & 54.0 & 69.0 & 152\end{array}$

$\begin{array}{lllllllllll}\text { BUY-4 } & 21.5 & -20.8 & -10.1 & -4.6 & 6.2 & 16.0 & 30.7 & 54.6 & 72.6 & 159\end{array}$

$\begin{array}{lllllllllll}\text { BUY-5 } & 21.2 & -18.6 & -9.6 & -4.0 & 5.0 & 17.0 & 31.5 & 55.6 & 73.2 & 114\end{array}$

$\begin{array}{lllllllllll}\text { BUY-6 } & 22.9 & -16.8 & -7.0 & -4.0 & 6.5 & 17.0 & 33.5 & 58.0 & 76.0 & 137\end{array}$

$\begin{array}{lllllllllll}\text { BUY-7 } & 24.7 & -14.7 & -8.5 & -3.0 & 9.0 & 19.0 & 36.7 & 63.1 & 78.1 & 178\end{array}$

$\begin{array}{lllllllllll}\text { BUY-8 } & 24.2 & -13.7 & -8.6 & -0.6 & 8.0 & 19.0 & 36.2 & 62.3 & 75.0 & 90\end{array}$ 
TABLE 14

COMMON SHARES OUTSTANDING AND TRADING VOLUME FOR THE 222 GREATEST WINNERS IN THE SELL, BUY, AND EIGHT PRECEDING QUARTERS

Panel A: Common Shares Outstanding (in 000s)

Percentile

Quarter Mean 1st 5th 10th 25th 50th 75th 90th 95th 99th

$\begin{array}{lllllllllll}\text { SELL } & 23360 & 1431 & 2034 & 2985 & 5895 & 10925 & 25652 & 47805 & 65924 & 328405\end{array}$

$\begin{array}{lllllllllll}\text { BUY } & 13885 & 712 & 1301 & 1583 & 2637 & 5740 & 11355 & 21113 & 34899 & 308358\end{array}$

$\begin{array}{lllllllllll}\text { BUY-1 } & 13197 & 712 & 1257 & 1506 & 2577 & 5145 & 10832 & 19317 & 34827 & 281323\end{array}$

$\begin{array}{lllllllllll}\text { BUY-2 } & 13098 & 712 & 1131 & 1493 & 2557 & 4955 & 10767 & 19317 & 34258 & 281323\end{array}$

$\begin{array}{lllllllllll}\text { BUY-3 } & 13110 & 711 & 1110 & 1434 & 2540 & 4930 & 10845 & 18652 & 33114 & 294743\end{array}$

$\begin{array}{lllllllllll}\text { BUY-4 } & 12834 & 710 & 1110 & 1420 & 2560 & 5050 & 11320 & 18820 & 32490 & 315620\end{array}$

$\begin{array}{lllllllllll}\text { BUY-5 } & 12883 & 705 & 1110 & 1414 & 2522 & 5110 & 11275 & 19033 & 32518 & 323784\end{array}$

$\begin{array}{lllllllllll}\text { BUY-6 } & 12915 & 680 & 1116 & 1420 & 2440 & 5090 & 11320 & 19388 & 30762 & 337393\end{array}$

$\begin{array}{llllllllllll}\text { BUY-7 } & 12899 & 678 & 1115 & 1380 & 2385 & 5090 & 10955 & 19590 & 30975 & 342838\end{array}$

$\begin{array}{llllllllllll}\text { BUY-8 } & 12871 & 677 & 1111 & 1359 & 2387 & 4875 & 10712 & 19302 & 31755 & 360903\end{array}$

Panel B: Average Daily Trading Volume (last 50 trading days, in 00s)

Percentile

Quarter Mean 1st 5th 10th 25th 50th 75th 90th 95th 99th

$\begin{array}{lllllllllll}\text { SELL } & 619 & 23.8 & 40.0 & 53.2 & 118 & 290 & 569 & 1420 & 2574 & 7040\end{array}$

$\begin{array}{lllllllllll}\text { BUY } & 317 & 6.6 & 17.3 & 26.3 & 53 & 123 & 259 & 528 & 858 & 5708\end{array}$

$\begin{array}{lllllllllll}\text { BUY-1 } & 201 & 0.0 & 8.1 & 13.0 & 32 & 74 & 178 & 391 & 672 & 3619\end{array}$

$\begin{array}{lllllllllll}\text { BUY-2 } & 206 & 0.0 & 8.0 & 12.3 & 30 & 76 & 171 & 364 & 764 & 4510\end{array}$

$\begin{array}{lllllllllll}\text { BUY-3 } & 184 & 0.0 & 7.0 & 11.0 & 32 & 78 & 176 & 373 & 505 & 2247\end{array}$

$\begin{array}{lllllllllll}\text { BUY-4 } & 163 & 0.0 & 7.0 & 11.0 & 30 & 76 & 168 & 356 & 503 & 2383\end{array}$

$\begin{array}{lllllllllll}\text { BUY-5 } & 183 & 0.0 & 3.9 & 10.8 & 27 & 73 & 174 & 315 & 517 & 3929\end{array}$

$\begin{array}{lllllllllll}\text { BUY-6 } & 178 & 0.0 & 3.0 & 7.0 & 26 & 65 & 166 & 327 & 546 & 4156\end{array}$

$\begin{array}{lllllllllll}\text { BUY-7 } & 175 & 0.0 & 2.7 & 9.0 & 27 & 62 & 160 & 312 & 456 & 3853\end{array}$

$\begin{array}{lllllllllll}\text { BUY-8 } & 175 & 0.0 & 4.0 & 8.8 & 26 & 74 & 163 & 304 & 526 & 3304\end{array}$ 
TABLE 15

RATIO OF PRICE ON BUY DATE TO MAXIMUM PRICE DURING PREVIOUS 2 YEARS FOR THE 222 GREATEST WINNERS

\begin{tabular}{lrrrrr} 
& & \multicolumn{4}{c}{ Percentiles } \\
Mean & 0.899 & $5 \%$ & 0.699 & $95 \%$ & 1.000 \\
Median & 0.922 & $10 \%$ & 0.785 & $90 \%$ & 0.996 \\
& & $25 \%$ & 0.871 & $75 \%$ & 0.969
\end{tabular}

Note: These figures are computed by dividing the price of the stock on the buy date by its maximum price during the previous 2 year period. All prices have been adjusted for stock splits. 
TABLE 16

\section{DISTRIBUTION OF CUMULATIVE EXCESS HOLDING PERIOD RETURNS EARNED BY THE STRATEGY BASED ON NINE INVESTMENT SCREENS (returns are in percentages)}

\begin{tabular}{|c|c|c|c|c|c|c|c|c|c|c|}
\hline \multirow[b]{2}{*}{ Quarter } & \multicolumn{10}{|c|}{ Percentile } \\
\hline & Mean & $1 s t$ & 5th & 10th & 25 th & 50 th & 75th & 90th & 95th & 99th \\
\hline $\mathrm{BUY}^{+1}$ & 8.02 & -25.0 & -16.7 & -10.6 & -2.9 & 6.4 & 17.5 & 27.9 & 36.2 & 63.7 \\
\hline $\mathrm{BUY}^{+} 2$ & 16.06 & -30.3 & -21.5 & -13.3 & -2.9 & 12.7 & 27.8 & 47.6 & 68.0 & 124.6 \\
\hline $\mathrm{BUY}^{+} 3$ & 24.10 & -31.6 & -22.6 & -14.5 & -0.0 & 18.4 & 42.3 & 66.5 & 84.6 & 150.5 \\
\hline $\mathrm{BUY}^{+} 4$ & 32.73 & -34.3 & -23.9 & -14.4 & 0.3 & 23.8 & 55.4 & 94.5 & 118.8 & 186.6 \\
\hline $\mathrm{BUY}^{+} 5$ & 40.81 & -38.9 & -22.8 & -14.6 & 2.8 & 28.2 & 64.1 & 106.7 & 143.7 & 232.4 \\
\hline $\mathrm{BUY}^{+} 6$ & 52.16 & -52.6 & -26.3 & -15.5 & 5.1 & 33.3 & 77.4 & 137.3 & 179. & 318.6 \\
\hline $\mathrm{BUY}^{+} 7$ & 57.19 & -48.2 & -30.7 & -16.0 & 9.1 & 41.1 & 88.0 & 149.1 & 193.5 & 348.0 \\
\hline $\mathrm{BUY}^{+} 8$ & 65.77 & -52.7 & -30.3 & -17.0 & 6.9 & 49.1 & 98.9 & 167.6 & 220.4 & 376.8 \\
\hline
\end{tabular}

Notes: An excess return is defined as the difference between the holding period return of the security and the holding period return of the S\&P 500 Index over the same period of time. A buy signal is issued for the firm when the following conditions are met: (1) the price/book ratio is less than 1; (2) the five-year earnings growth rate is positive; (3) earnings are accelerating; (4) pretax profit margins are positive; (5) number of common shares outstanding is less than 20 million; (6) the O'Neil datagraph rating is at least 70; (7) the stock is selling within 15 percent of its high during the previous 2 years; (8) the relative strength rating of the stock is at least 70; and (9) the relative strength of the stock is greater in the current quarter than in the previous quarter. 
TABLE 17

\section{DISTRIBUTION OF CUMULATIVE EXCESS HOLDING PERIOD RETURNS EARNED BY THE STRATEGY BASED ON NINE INVESTMENT SCREENS EXCLUDING FIRMS ON THE LIST OF 222 GREATEST WINNERS (returns are in percentages)}

\begin{tabular}{|c|c|c|c|c|c|c|c|c|c|c|}
\hline \multirow[b]{2}{*}{ Quarter } & \multicolumn{10}{|c|}{ Percentile } \\
\hline & Mean & $1 s t$ & 5 th & 10th & 25th & 50 th & 75th & 90th & 95th & 99th \\
\hline $\mathrm{UY}^{+} 1$ & 5.9 & -24.7 & -18.2 & -12.2 & -3.7 & 4.7 & 14.8 & 26.0 & 31.6 & 46.2 \\
\hline $3 \mathrm{UY}+2$ & 11.5 & -30.0 & -22.1 & -13.8 & -5.2 & 9.8 & 22.6 & 37.1 & 54.1 & 89.6 \\
\hline $\mathrm{BUY}^{+} 3$ & 18.2 & -34.6 & -23.1 & -17.4 & -2.7 & 14.7 & 34.5 & 55.8 & 72.2 & 133.4 \\
\hline $\mathrm{BUY}^{+} 4$ & 23.7 & -36.0 & -25.4 & -17.7 & -3.8 & 17.4 & 43.5 & 74.1 & 96.8 & 158.2 \\
\hline $\mathrm{BUY}+5$ & 30.2 & -40.4 & -25.1 & -16.5 & -2.3 & 20.5 & 51.7 & 91.2 & 113.3 & 182.6 \\
\hline $\mathrm{BUY}^{+} 6$ & 37.8 & -56.5 & -29.0 & -18.2 & 0.1 & 27.6 & 62.6 & 114.5 & 144.3 & 219.9 \\
\hline $\mathrm{BUY}^{+} 7$ & 44.0 & -53.1 & -33.6 & -18.7 & 5.5 & 34.5 & 71.1 & 126.1 & 160.1 & 242.3 \\
\hline $\mathrm{BUY}^{+} 8$ & 50.6 & -56.2 & -32.4 & -20.2 & 5.1 & 39.4 & 83.4 & 132.0 & 170.1 & 303.8 \\
\hline
\end{tabular}

Notes: An excess return is defined as the difference between the holding period return of the security and the holding period return of the S\&P 500 Index over the same period of time. A buy signal is issued for the firm when the following conditions are met: (1) the price/book ratio is less than 1 ; (2) the five-year quarterly earnings growth rate is positive; (3) earnings are accelerating; (4) pretax profit margins are positive; (5) number of common shares outstanding is less than 20 million; (6) the O'Neil datagraph rating is at least 70; (7) the stock is selling within 15 percent of its high during the previous 2 years; $(8)$ the relative strength rating of the stock is at least 70; and (9) the relative strength of the stock is greater in the current quarter than in the previous quarter. Any firm that was classified as one of the 222 greatest winners is excluded from this strategy. 
TABLE 18

BETAS, STOCK MARKET CAPITALIZATIONS, SHARE PRICES AND SHARES OUTSTANDING AMONG FIRMS SELECTED BY THE STRATEGY WITH NINE INVESTMENT SCREENS

(excluding any firm on the list of 222 greatest winners)

\section{Panel A: Betas}

\begin{tabular}{llrrrr} 
& & \multicolumn{4}{c}{ Percentiles } \\
Mean & 1.03 & $5 \%$ & 0.29 & $95 \%$ & 1.95 \\
Median & 0.99 & $10 \%$ & 0.45 & $90 \%$ & 1.66 \\
& & $25 \%$ & 0.69 & $75 \%$ & 1.34
\end{tabular}

Note: Betas are calculated relative to the S\&P 500 index using weekly returns during the period 2 years prior to the buy date.

Panel B: Stock Market Capitalizations (in \$ millions)

\begin{tabular}{lrrrrr} 
& & \multicolumn{4}{c}{ Percentiles } \\
Mean & 182.9 & $5 \%$ & 11.0 & $95 \%$ & 614.0 \\
Median & 102.3 & $10 \%$ & 19.6 & $90 \%$ & 441.9 \\
& & $25 \%$ & 40.8 & $75 \%$ & 241.3
\end{tabular}

Panel C: Share Prices (in \$)

\begin{tabular}{lrrrrr} 
& & \multicolumn{4}{c}{ Percentiles } \\
Mean & 28.21 & $5 \%$ & 7.88 & $95 \%$ & 58.50 \\
Median & 26.25 & $10 \%$ & 11.30 & $90 \%$ & 45.70 \\
& & $25 \%$ & 18.25 & $75 \%$ & 34.82
\end{tabular}

Panel D: Common Shares Outstanding (in 000s)

\begin{tabular}{lrrrrr} 
& & \multicolumn{4}{c}{ Percentiles } \\
Mean & 5649 & $5 \%$ & 921 & $95 \%$ & 15052 \\
Median & 3958 & $10 \%$ & 1246 & $90 \%$ & 12797 \\
& & $25 \%$ & 2108 & $75 \%$ & 7890
\end{tabular}


TABLE 19

\section{DISTRIBUTION OF CUMULATIVE EXCESS HOLDING PERIOD RETURNS EARNED BY THE STRATEGY BASED ON \\ ALL NINE INVESTMENT SCREENS EXCEPT FOR PRICE/BOOK RATIOS LESS THAN ONE (excludes 222 winners, 1970-1983)}

\begin{tabular}{|c|c|c|c|c|c|c|c|c|c|c|}
\hline \multirow[b]{2}{*}{ Quarter } & \multicolumn{10}{|c|}{ Percentile } \\
\hline & Mean & $1 \mathrm{st}$ & 5 th & 10 th & 25th & 50 th & 75th & 90th & 95th & 99th \\
\hline $\mathrm{BUY}^{+} 1$ & 3.9 & -28.2 & -19.2 & -14.1 & -5.4 & 2.7 & 12.6 & 23.4 & 30.1 & 48.6 \\
\hline $\mathrm{BUY}^{+2}$ & 7.9 & -36.7 & -23.3 & -18.0 & -8.7 & 5.3 & 19.7 & 35.0 & 48.1 & 89.6 \\
\hline $\mathrm{BUY}^{+} 3$ & 11.6 & -46.8 & -30.4 & -22.4 & -8.8 & 8.5 & 27.9 & 48.5 & 63.8 & 98.6 \\
\hline $\mathrm{BUY}^{+} 4$ & 14.6 & -55.3 & -35.3 & -26.4 & -10.7 & 8.5 & 33.4 & 61.6 & 85.5 & 131.5 \\
\hline $\mathrm{BUY}^{+} 5$ & 17.9 & -68.3 & -42.4 & -30.8 & -11.7 & 10.7 & 40.5 & 81.2 & 99.4 & 145.0 \\
\hline $\mathrm{BUY}^{+} 6$ & 22.7 & -70.4 & -50.1 & -30.8 & -12.7 & 13.1 & 47.4 & 95.7 & 125.1 & 185.0 \\
\hline $\mathrm{BUY}^{+} 7$ & 25.8 & -79.2 & -53.1 & -38.0 & -12.2 & 15.5 & 57.8 & 97.0 & 135.6 & 200.0 \\
\hline $\mathrm{BUY}^{+8}$ & 30.6 & -85.3 & -58.2 & -41.2 & -12.9 & 21.1 & 64.5 & 113.1 & 146.5 & 277 \\
\hline
\end{tabular}

Notes: An excess return is defined as the difference between the holding period return of the security and the holding period return of the $S \& P$ 500 Index over the same period of time. A buy signal is issued for the firm when the following conditions are met: (1) the five-year quarterly earnings growth rate is positive; (2) earnings are accelerating; (3) pre-tax profit margins are positive; (4) number of common shares outstanding is less than 20 million; (5) the O'Neil datagraph rating is at least 70; (6) the stock is selling within 15 percent of its high during the previous 2 years; (7) the relative strength rating of the stock is at least 70; and (8) the relative strength of the stock is greater in the current quarter than in the previous quarter. Any firm that was classified as one of the 222 greatest winners is excluded from this strategy. All excess returns are expressed as percentages. 
TABLE 20

\section{DISTRIBUTION OF CUMULATIVE EXCESS HOLDING PERIOD RETURNS EARNED BY THE STRATEGY BASED ON ALL NINE INVESTMENT SCREENS EXCEPT FOR DATAGRAPH RATINGS GREATER THAN 70 (excludes 222 winners, 1970-1983)}

\begin{tabular}{|c|c|c|c|c|c|c|c|c|c|c|}
\hline \multirow[b]{2}{*}{ Quarter } & \multicolumn{10}{|c|}{ Percentile } \\
\hline & Mean & $1 \mathrm{st}$ & 5 th & 10 th & 25 th & 50 th & 75th & 90 th & 95th & 99th \\
\hline & 3.9 & -28.2 & & -14.1 & -5.4 & 2.7 & 12.6 & 23.4 & 30.1 & 40 \\
\hline & 4 & -25.4 & & -11.8 & -3.59 & 5.3 & 14.8 & 26.1 & 32.8 & \\
\hline & 11.2 & & -20.1 & -13.3 & -4.61 & 9.2 & 22.2 & 39.3 & 53.2 & \\
\hline & 16.8 & -35.9 & -22.2 & -16.3 & -3.47 & 13.0 & 30.5 & 54.8 & 68.1 & 127 \\
\hline & 21.2 & -37.0 & -25.7 & -18.1 & -4.51 & 15.8 & 39.0 & 65.5 & 87.6 & . \\
\hline & 27.6 & -42.4 & -28.8 & -18.8 & -3.57 & 19.6 & 47.8 & 82.9 & 106.5 & 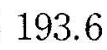 \\
\hline & 34.2 & -50.5 & -29.7 & -19.1 & 0.21 & 23.4 & 58.1 & 99.0 & 136.2 & 227 \\
\hline & 41.0 & -54.1 & -32.7 & -19.8 & 3.18 & 29.2 & 67.0 & 108.7 & 150.0 & 2 \\
\hline 8 & 45.9 & -56.0 & -31.0 & -18.5 & 5.55 & 32.9 & 75.3 & 124.0 & 160.1 & \\
\hline
\end{tabular}

Notes: An excess return is defined as the difference between the holding period return of the security and the holding period return of the S\&P 500 Index over the same period of time. A buy signal is issued for the firm when the following conditions are met: (1) the price/book ratio is less than 1; (2) the five-year quarterly earnings growth rate is positive; (3) earnings are accelerating; (4) pretax profit margins are positive; (5) number of common shares outstanding is less than 20 million; (6) the stock is selling within 15 percent of its high during the previous 2 years; (7) the relative strength rating of the stock is at least 70 ; and (8) the relative strength of the stock is greater in the current quarter than in the previous quarter. Any firm that was classified as one of the 222 greatest winners is excluded from this strategy. All excess returns are expressed as percentages. 
TABLE 21

\begin{abstract}
DISTRIBUTION OF CUMULATIVE EXCESS HOLDING PERIOD RETURNS EARNED BY THE STRATEGY BASED ON ALL NINE INVESTMENT SCREENS EXCEPT FOR RELATIVE STRENGTH AND DATAGRAPH RATINGS FILTERS (excludes 222 winners, 1970-1983)
\end{abstract}

Percentile

\begin{tabular}{|c|c|c|c|c|c|c|c|c|c|c|}
\hline uarter & Mean & $1 \mathrm{st}$ & 5 th & 10th & 25 th & 50 th & 75th & 90th & 95th & 99th \\
\hline DIVY & 4.3 & -23.9 & -15.7 & -11.1 & -4.3 & 3.4 & 11.2 & 20.8 & 27.9 & 1.0 \\
\hline BUY & 8.5 & -32.2 & -20.0 & -14.4 & -4.7 & 6.4 & 18.1 & 32.5 & 42.8 & 76.0 \\
\hline & 13.3 & -35.1 & -22.8 & -15.9 & -4.0 & 10.4 & 26.0 & 43.9 & 2 & \\
\hline $\mathrm{BU}$ & 17.3 & -37.8 & -24.7 & -17.0 & -3.5 & 13.8 & 31.7 & 54.1 & 72.9 & \\
\hline 5 & 22.0 & -44.4 & -28.5 & -19.1 & -3.9 & 16.5 & 39.6 & 68.3 & 91.5 & \\
\hline $3 \mathrm{UY}^{+} 6$ & 26.3 & -48.7 & -30.1 & -19.8 & -2.5 & 18.1 & 46.5 & 78.6 & 107.0 & .0 \\
\hline $\mathrm{BUY}^{+} 7$ & 30.7 & -54.9 & -32.6 & -22.0 & -2.6 & 22.3 & 52.5 & 90.7 & 123.6 & 202.5 \\
\hline $3 \mathrm{UY}^{+}+8$ & 36.0 & 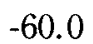 & 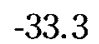 & 7 & .3 & 26.2 & t. & 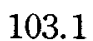 & 2 & \\
\hline
\end{tabular}

Notes: An excess return is defined as the difference between the holding period return of the security and the holding period return of the S\&P 500 Index over the same period of time. A buy signal is issued for the firm when the following conditions are met: (1) the price/book ratio is less than 1; (2) the five-year quarterly earnings growth rate is positive; (3) earnings are accelerating; (4) pretax profit margins are positive; (5) number of common shares outstanding is less than 20 million; (6) the stock is selling within 15 percent of its high during the previous 2 years. Any firm that was classified as one of the 222 greatest winners is excluded from this strategy. All excess returns are expressed as percentages. 
TABLE 22

\section{DISTRIBUTION OF CUMULATIVE EXCESS HOLDING PERIOD RETURNS EARNED BY THE STRATEGY BASED ON ALL NINE INVESTMENT SCREENS EXCEPT FOR THE THREE EARNINGS FILTERS AND THE DATAGRAPH RATINGS FILTER (excludes 222 winners, 1970-1983)}

\begin{tabular}{|c|c|c|c|c|c|c|c|c|c|c|}
\hline \multirow[b]{2}{*}{ Quarter } & \multicolumn{10}{|c|}{ Percentile } \\
\hline & Mean & 1 st & 5 th & 10 th & 25th & 50 th & 75th & 90 th & 95th & 99th \\
\hline BUY & 4.7 & -31.4 & -20.1 & -14.5 & -5.6 & 3.1 & 13.0 & 24.6 & 34.7 & 60.7 \\
\hline $\mathrm{BUY}+2$ & 8.6 & -38.9 & -26.7 & -19.0 & -6.9 & 6.1 & 19.9 & 37.2 & 51.8 & 92.4 \\
\hline $\mathrm{BUY}+3$ & 12.9 & -46.5 & -30.5 & -22.4 & -7.8 & 8.5 & 27.4 & 50.4 & 68.4 & 136.3 \\
\hline $\mathrm{BUY}^{+} 4$ & 17.1 & -54.0 & -34.6 & -25.5 & -8.9 & 11.0 & 35.1 & 63.2 & 87.2 & 157.1 \\
\hline $\mathrm{BUY}^{+} 5$ & 21.1 & -60.8 & -39.8 & -29.2 & -9.7 & 13.2 & 41.1 & 76.2 & 105.3 & 198.7 \\
\hline $\mathrm{BUY}^{+} 6$ & 24.8 & -64.7 & -44.6 & -31.8 & -9.7 & 15.0 & 47.8 & 87.8 & 123.4 & 233.2 \\
\hline $\mathrm{BUY}^{+} 7$ & 29.8 & -68.3 & -47.1 & -32.5 & -9.4 & 17.1 & 54.1 & 100.7 & 139.2 & 259.5 \\
\hline $\mathrm{BUY}+8$ & 34.5 & -71.7 & -49.2 & -32.9 & -9.0 & 20.4 & 62.0 & 113.2 & 155.4 & 299.2 \\
\hline
\end{tabular}

Notes: An excess return is defined as the difference between the holding period return of the security and the holding period return of the S\&P 500 Index over the same period of time. A buy signal is issued for the firm when the following conditions are met: (1) the price/book ratio is less than 1 ; (2) number of common shares outstanding is less than 20 million; (3) the stock is selling within 15 percent of its high during the previous 2 years; (4) the relative strength rating of the stock is at least 70 ; and (5) the relative strength of the stock is greater in the current quarter than in the previous quarter. Any firm that was classified as one of the 222 greatest winners is excluded from this strategy. All excess returns are expressed in percentages. 
TABLE 23

DISTRIBUTION OF CUMULATIVE EXCESS HOLDING PERIOD RETURNS EARNED BY THE STRATEGY BASED ON ONLY THE PRICE/BOOK, INCREASING RELATIVE STRENGTH AND ACCELERATING EARNINGS SCREENS (excludes 222 winners, 1970-1983)

\begin{tabular}{|c|c|c|c|c|c|c|c|c|c|c|}
\hline \multirow[b]{2}{*}{ Quarter } & \multicolumn{10}{|c|}{ Percentile } \\
\hline & Mean & 1 st & 5th & 10th & 25th & 50th & 75th & 90th & 95th & 99th \\
\hline $\mathrm{BUY}^{+} 1$ & 2.8 & -35.8 & -23.1 & -16.9 & -7.4 & 1.6 & 10.7 & 22.6 & 33.2 & 63.8 \\
\hline $\mathrm{BUY}^{+} 2$ & 7.0 & -43.9 & -28.3 & -20.5 & -8.2 & 4.0 & 17.7 & 36.1 & 51.7 & 100.2 \\
\hline $\mathrm{BUY}^{+} 3$ & 10.7 & -53.9 & -33.8 & -24.4 & -9.2 & 6.3 & 24.4 & 47.5 & 66.9 & 137.6 \\
\hline $\mathrm{BUY}^{+} 4$ & 14.6 & -57.8 & -36.9 & -26.5 & -9.7 & 8.9 & 30.5 & 58.9 & 84.6 & 158.9 \\
\hline $\mathrm{BUY}^{+} 5$ & 18.3 & -64.0 & -42.4 & -29.9 & -10.3 & 11.0 & 36.8 & 70.9 & 100.8 & 192.7 \\
\hline $\mathrm{BUY}^{+} 6$ & 22.6 & -69.0 & -44.5 & -30.3 & -9.8 & 13.2 & 42.6 & 82.8 & 117. & 224.0 \\
\hline $\mathrm{BUY}^{+} 7$ & 26.9 & -70.7 & -46.2 & -33.3 & -9.8 & 15.9 & 48.8 & 95. & 134. & 246.9 \\
\hline $\mathrm{BUY}^{+} 8$ & 32.0 & -75.6 & -47.5 & -32.7 & -8.6 & 19.3 & 56.1 & 106.6 & 148.3 & 285.9 \\
\hline
\end{tabular}

Notes: An excess return is defined as the difference between the holding period return of the security and the holding period return of the S\&P 500 Index over the same period of time. A buy signal is issued for the firm when the following conditions are met: (1) the price/book ratio is less than 1; (2) earnings are accelerating; and (3) the relative strength of the stock is greater in the current quarter than in the previous quarter. Any firm that was classified as one of the 222 greatest winners is excluded from this strategy. All excess returns are expressed in percentages. 
TABLE 24

\section{DISTRIBUTION OF CUMULATIVE EXCESS HOLDING PERIOD RETURNS EARNED BY THE STRATEGY BASED ON NINE INVESTMENT SCREENS (1984-1986)}

\begin{tabular}{|c|c|c|c|c|c|c|c|c|c|c|}
\hline \multirow[b]{2}{*}{ Quarter } & \multicolumn{10}{|c|}{ Percentile } \\
\hline & Mean & 1st & 5 th & 10th & 25 th & 50 th & 75th & 90th & 95th & 99th \\
\hline $\mathrm{BUY}^{+}$ & 4.2 & -47.6 & -17.6 & -16.7 & -1.1 & 3.2 & 12.6 & 21.3 & 32.5 & 37.5 \\
\hline $\mathrm{BUY}^{+2}$ & 11.8 & -46.2 & -33.0 & -14.0 & -3.1 & 8.1 & 28.7 & 49.4 & 60.2 & 96.4 \\
\hline $\mathrm{BUY}^{+} 3$ & 14.6 & -52.4 & -37.4 & -15.9 & -3.8 & 10.5 & 27.7 & 58.9 & 66.3 & 98.3 \\
\hline $\mathrm{BUY}^{+} 4$ & 22.2 & -37.7 & -32.0 & -17.0 & 5.8 & 15.8 & 40.4 & 66.6 & 87.5 & 94.5 \\
\hline $\mathrm{BUY}^{+} 5$ & 25.0 & -62.0 & -46.8 & -22.5 & -2.1 & 21.6 & 51.6 & 72.9 & 114.4 & 144.6 \\
\hline $\mathrm{BUY}^{+} 6$ & 29.9 & -62.0 & -59.2 & -53.8 & 10.3 & 32.3 & 51.4 & 85.0 & 124.4 & 137.0 \\
\hline $\mathrm{BUY}^{+} 7$ & 34.5 & -62.7 & -58.4 & -44.8 & 2.2 & 34.3 & 63.0 & 83.9 & 123.3 & 136.9 \\
\hline $\mathrm{BUY}^{+} 8$ & 36.7 & -52.4 & -47.2 & -20.1 & 5.0 & 29.2 & 77.4 & 99.7 & 106.9 & 107.4 \\
\hline
\end{tabular}

Notes: An excess return is defined as the difference between the holding period return of the security and the holding period return of the S\&P 500 Index over the same period of time. A buy signal is issued for the firm when the following conditions are met: (1) the price/book ratio is less than 1; (2) the five-year quarterly earnings growth rate is positive; (3) earnings are accelerating; (4) pretax profit margins are positive; (5) number of common shares outstanding is less than 20 million; (6) the O'Neil datagraph rating is at least 70; (7) the stock is selling within 15 percent of its high during the previous 2 years; (8) the relative strength rating of the stock is at least 70; and (9) the relative strength of the stock is greater in the current quarter than in the previous quarter. All excess returns are expressed in percentages. 
TABLE 25

\section{DISTRIBUTION OF CUMULATIVE EXCESS HOLDING PERIOD RETURNS EARNED BY THE STRATEGY BASED ON ALL NINE INVESTMENT SCREENS EXCEPT FOR PRICE/BOOK RATIOS LESS THAN ONE (1984-1986)}

\begin{tabular}{|c|c|c|c|c|c|c|c|c|c|c|}
\hline \multirow[b]{2}{*}{ Quarter } & \multirow[b]{2}{*}{ Mean } & \multicolumn{9}{|c|}{ Percentile } \\
\hline & & 1 st & 5 th & 10th & 25th & 50th & 75th & 90th & 95th & 99th \\
\hline $\mathrm{BUY}^{+}$ & 2.7 & -34.3 & -20.8 & -17.0 & -7.3 & 2.5 & 12.3 & 22.0 & 33.1 & 51.7 \\
\hline $\mathrm{BUY}^{+2}$ & 6.2 & -45.8 & -32.4 & -21.7 & -9.6 & 4.1 & 18.5 & 35.4 & 53.6 & 93.3 \\
\hline $\mathrm{BUY}^{+} 3$ & 7.4 & -60.1 & -39.9 & -29.1 & -12.9 & 4.5 & 23.1 & 43.3 & 70.2 & 107.1 \\
\hline $\mathrm{BUY}^{+} 4$ & 11.4 & -72.0 & -43.3 & -34.3 & -13.0 & 7.5 & 35.1 & 62.0 & 83.7 & 156.6 \\
\hline $\mathrm{BUY}^{+} 5$ & 12.3 & -80.5 & -58.7 & -44.7 & -14.7 & 8.8 & 39.9 & 63.8 & 108.9 & 150.6 \\
\hline $\mathrm{BUY}^{+} 6$ & 9.1 & -101.7 & -71.7 & -58.9 & -29.8 & 11.1 & 36.2 & 72.7 & 112.3 & 270.8 \\
\hline $\mathrm{BUY}^{+} 7$ & 10.4 & -106.2 & -80.4 & -62.2 & -41.4 & 1.6 & 52.9 & 76.6 & 119.2 & 282.9 \\
\hline $\mathrm{BUY}^{+} 8$ & 14.0 & -120.3 & -99.2 & -72.6 & -34.1 & 12.0 & 54.0 & 95.6 & 106.5 & 380.9 \\
\hline
\end{tabular}

Notes: An excess return is defined as the difference between the holding period return of the security and the holding period return of the S\&P 500 Index over the same period of time. A buy signal is issued for the firm when the following conditions are met: (1) the five-year quarterly earnings growth rate is positive; (2) earnings are accelerating; (3) pre-tax profit margins are positive; (4) number of common shares outstanding is less than 20 million; (5) the O'Neil datagraph rating is at least 70; (6) the stock is selling within 15 percent of its high during the previous 2 years; (7) the relative strength rating of the stock is at least 70 ; and (8) the relative strength of the stock is greater in the current quarter than in the previous quarter. All excess returns are expressed in percentages. 
TABLE 26

\section{DISTRIBUTION OF CUMULATIVE EXCESS HOLDING PERIOD RETURNS EARNED BY THE STRATEGY BASED ON ALL NINE INVESTMENT SCREENS EXCEPT FOR DATAGRAPH RATINGS GREATER THAN 70 (1984-1986)}

Percentile

\begin{tabular}{|c|c|c|c|c|c|c|c|c|c|c|}
\hline Quarter & Mean & $1 \mathrm{st}$ & 5 th & 10th & 25 th & 50 th & 75th & 90th & 95th & 99th \\
\hline $\mathrm{BUY}^{+} \mathbf{1}$ & 3.8 & -45.9 & -17.0 & -10.0 & -3.6 & 2.9 & 9.1 & 17.3 & 25.2 & \\
\hline $\mathrm{BUY}^{+} 2$ & 10.4 & -45.1 & -29.8 & -14.5 & -1.1 & 9.3 & 17.7 & 34.5 & 54.7 & 117.3 \\
\hline $\mathrm{BUY}^{+} 3$ & 14.3 & -50.7 & -32.4 & -22.6 & -1.0 & 13.8 & 24.9 & 44.7 & 1. & 1 \\
\hline $\mathrm{BUY}^{+} 4$ & 18.8 & -46.1 & -37.0 & -25.1 & 5.6 & 15.4 & 32.3 & 61.2 & 73.9 & 248.6 \\
\hline $\mathrm{BUY}^{+} 5$ & 22.8 & -72.6 & -43.7 & -24.7 & 3.9 & 21.6 & 40.0 & 64.5 & 82 . & 200. \\
\hline $\mathrm{BUY}^{+} 6$ & 25.3 & -77.4 & -58.4 & -32.0 & 1.4 & 25.3 & 46.7 & 84.4 & 110.0 & 137.0 \\
\hline $\mathrm{BUY}^{+} 7$ & 31.9 & -96.2 & -72.8 & -46.7 & 12.2 & 33.5 & 61.2 & 81.7 & 122.5 & 181.4 \\
\hline $\mathrm{BUY}^{+} 8$ & 31.1 & -130.8 & -73.5 & -43.4 & 4.6 & 36.8 & 64.9 & 82.1 & 09 & $178=$ \\
\hline
\end{tabular}

Notes: An excess return is defined as the difference between the holding period return of the security and the holding period return of the S\&P 500 Index over the same period of time. A buy signal is issued for the firm when the following conditions are met: (1) the price/book ratio is less than 1; (2) the five-year quarterly earnings growth rate is positive; (3) earnings are accelerating; (4) pretax profit margins are positive; (5) number of common shares outstanding is less than 20 million; (6) the stock is selling within 15 percent of its high during the previous 2 years; (7) the relative strength rating of the stock is at least 70 ; and (8) the relative strength of the stock is greater in the current quarter than in the previous quarter. All excess returns are expressed in percentages. 
TABLE 27

DISTRIBUTION OF CUMULATIVE EXCESS HOLDING PERIOD RETURNS EARNED BY THE STRATEGY BASED ON ALL NINE INVESTMENT SCREENS EXCEPT FOR RELATIVE STRENGTH AND DATAGRAPH RATINGS FILTERS (1984-1986)

\begin{tabular}{|c|c|c|c|c|c|c|c|c|c|}
\hline \multirow[b]{2}{*}{ Quarter } & \multicolumn{9}{|c|}{ Percentile } \\
\hline & Mean & 1 st & 5 th & 10 th & 25 th & 50 th & 75th & 90 th & 95th 99 th \\
\hline & 3.6 & 4.0 & -10.4 & & -3.3 & 2.5 & 9.2 & 16.0 & $24.3 \quad 60.4$ \\
\hline $\mathrm{BUY}^{+} 2$ & 8.4 & -45.0 & -26.7 & -16.9 & -3.8 & 8.9 & 17.4 & 32.2 & 46.2106 .4 \\
\hline & 12.2 & -56.0 & -33.7 & -27.9 & -3.6 & 13.1 & 24.5 & 44.2 & 64.5142 .9 \\
\hline $\mathrm{BUY}^{+} 4$ & 16.6 & -59.4 & -37.4 & -25.6 & -1.2 & 14.6 & 29.4 & 60.2 & 74.1183 .6 \\
\hline $\mathrm{BUY}^{+} 5$ & 22.5 & -77.0 & -43.2 & -26.5 & 0.0 & 21.8 & 40.8 & 69.8 & 86.9181 .9 \\
\hline $\mathrm{BUY}^{+} 6$ & 26.5 & -81.9 & -51.6 & -32.5 & 1.4 & 28.5 & 49.6 & 80.3 & 113.5136 .9 \\
\hline $\mathrm{BUY}^{+} 7$ & 30.8 & -122.8 & -75.5 & -45.7 & 8.0 & 37.1 & 60.2 & 87.9 & 123.2177 .7 \\
\hline $\mathrm{BUY}^{+} 8$ & 30.5 & -130.8 & -85.3 & -48.3 & 5.2 & 36.8 & 65.0 & 86.3 & 106.5176 .7 \\
\hline
\end{tabular}

Notes: An excess return is defined as the difference between the holding period return of the security and the holding period return of the S\&P 500 Index over the same period of time. A buy signal is issued for the firm when the following conditions are met: (1) the price/book ratio is less than 1 ; (2) the five-year quarterly earnings growth rate is positive; (3) earnings are accelerating; (4) pretax profit margins are positive; (5) number of common shares outstanding is less than 20 million; (6) the stock is selling within 15 percent of its high during the previous 2 years. All excess returns are expressed as percentages. 
TABLE 28

\section{DISTRIBUTION OF CUMULATIVE EXCESS HOLDING PERIOD RETURNS EARNED BY THE STRATEGY BASED ON ALL NINE INVESTMENT SCREENS EXCEPT FOR THE THREE EARNINGS FILTERS AND THE DATAGRAPH RATINGS FILTER (1984-1986)}

\begin{tabular}{|c|c|c|c|c|c|c|c|c|c|c|}
\hline \multirow[b]{2}{*}{ Quarter } & \multirow[b]{2}{*}{ Mean } & \multicolumn{9}{|c|}{ Percentile } \\
\hline & & 1st & 5th & 10th & 25th & 50th & 75th & 90th & 95th & 99th \\
\hline $\mathrm{BUY}^{+} 1$ & 1.9 & -32.1 & -17.7 & -13.3 & -5.3 & 2.3 & 8.3 & 15.7 & 23.8 & 33.5 \\
\hline $\mathrm{BUY}^{+} 2$ & 5.9 & -42.6 & -27.4 & -19.3 & -7.4 & 5.7 & 15.3 & 29.2 & 41.0 & 85.7 \\
\hline $\mathrm{BUY}^{+} 3$ & 9.3 & -40.4 & -32.2 & -26.1 & -9.4 & 7.5 & 24.0 & 41.0 & 58.5 & 119.2 \\
\hline $\mathrm{BUY}^{+} 4$ & 13.3 & -54.6 & -37.6 & -26.1 & -10.5 & 9.7 & 28.7 & 53.4 & 76.1 & 144.7 \\
\hline $\mathrm{BUY}^{+} 5$ & 14.9 & -71.0 & -48.5 & -34.7 & -13.7 & 16.4 & 36.8 & 61.9 & 77.8 & 144.2 \\
\hline $\mathrm{BUY}^{+} 6$ & 17.2 & -77.5 & -51.8 & -38.6 & -12.8 & 20.5 & 40.8 & 69.7 & 95.2 & 136.9 \\
\hline $\mathrm{BUY}^{+} 7$ & 20.1 & -90.5 & -61.9 & -47.0 & -18.2 & 22.6 & 53.0 & 83.6 & 111.0 & 151.1 \\
\hline $\mathrm{BUY}^{+} 8$ & 21.3 & -116.0 & -75.5 & -60.4 & -24.4 & 26.4 & 63.4 & 82.5 & 105.0 & 166.9 \\
\hline
\end{tabular}

Notes: An excess return is defined as the difference between the holding period return of the security and the holding period return of the $S \& P$ 500 Index over the same period of time. A buy signal is issued for the firm when the following conditions are met: (1) the price/book ratio is less than 1; (2) number of common shares outstanding is less than 20 million; (3) the stock is selling within 15 percent of its high during the previous 2 years; (4) the relative strength rating of the stock is at least 70 ; and (5) the relative strength of the stock is greater in the current quarter than in the previous quarter. All excess returns are expressed in percentages. All returns are expressed in percentages. 
TABLE 29

\section{DISTRIBUTION OF CUMULATIVE EXCESS HOLDING PERIOD RETURNS EARNED BY THE STRATEGY BASED ON ONLY THE PRICE/BOOK, INCREASING RELATIVE STRENGTH AND ACCELERATING EARNINGS SCREENS (1984-1986)}

\begin{tabular}{|c|c|c|c|c|c|c|c|c|c|c|}
\hline \multirow[b]{2}{*}{ Quarter } & \multirow[b]{2}{*}{ Mean } & \multicolumn{9}{|c|}{ Percentile } \\
\hline & & $1 \mathrm{st}$ & 5 th & 10 th & 25 th & 50 th & 75 th & 90th & 95th & 99th \\
\hline $\mathrm{JY}^{+}$ & 1.6 & -35.1 & -19.4 & -14.2 & -5.4 & 2.3 & 8.6 & 15.3 & 21.3 & 37.1 \\
\hline $\mathrm{UY}^{+}$ & 3.7 & -45.8 & -29.2 & -20.0 & -9.0 & 4.5 & 15.5 & 25.0 & 35.4 & 58.9 \\
\hline $\mathrm{BUY}^{+} 3$ & 6.1 & -54.4 & -34.8 & -27.0 & -12.3 & 6.6 & 21.0 & 38.3 & 45.5 & 93.3 \\
\hline $\mathrm{BUY}^{+} 4$ & 8.5 & -60.7 & -42.0 & -28.3 & -12.5 & 7.9 & 25.2 & 42.8 & 61.4 & 99.7 \\
\hline $\mathrm{BUY}^{+} 5$ & 10.3 & -70.5 & -55.4 & -36.7 & -14.8 & 9.7 & 30.6 & 52.4 & 64.4 & 158.5 \\
\hline & 12.1 & -100.3 & -58.4 & -44.1 & -17.5 & 14.1 & 38.3 & 61.2 & 80.9 & 143.1 \\
\hline $\mathrm{BUY}^{+} 7$ & 14.9 & -113.9 & -66.2 & -55.0 & -21.9 & 18.1 & 50.4 & 76.4 & 92.4 & 140 \\
\hline $\mathrm{BUY}^{+} 8$ & 16.3 & -122.4 & -80.5 & -59.5 & -26.8 & 20.8 & 57.3 & 81.0 & 96.0 & 4 \\
\hline
\end{tabular}

Notes: An excess return is defined as the difference between the holding period return of the security and the holding period return of the S\&P 500 Index over the same period of time. A buy signal is issued for the firm when the following conditions are met: (1) the price/book ratio is less than 1; (2) earnings are accelerating; and (3) the relative strength of the stock is greater in the current quarter than in the previous quarter. All excess returns are expressed in percentages. 


\section{REFERENCES}

Alexander, Sidney S. "Price Movements in Speculative Markets: Trends or Random Walks." Industrial Management Review 2 (May 1961): 7-26.

Ariel, Robert A. "A Monthly Effect in Stock Returns." Journal of Financial Economics 18 (March 1987): 161-174.

Banz, Rolf W. "The Relationship Between Return and Market Value of Common Stocks." Journal of Financial Economics 9 (March 1981): 3-18.

Basu, Shanker. "The Investment Performance of Common Stocks in Relation to Their Price-Earnings Ratios: A Test of the Efficient Market Hypothesis." Journal of Finance 32 (June 1977): 663-682.

Chan, K.C. and Chen, Nai-Fu. "Estimation Error of Stock Betas and the Role of Firm Size as an Instrumental Variable for Risk." CRSP Working Paper \#179, University of Chicago, 1986.

Fama, Eugene F. "Efficient Capital Markets: A Review of Theory and Empirical Work." Journal of Finance 25 (May 1970): 383-417.

Fama, Eugene F. and Blume, Marshall E. "Filter Rules and Stock Market Trading." Journal of Business 39 (January 1966): 226-241.

French, Kenneth R. "Stock Returns and the Weekend Effect." Journal of Financial Economics 8 (March 1980): 55-69. 
Gibbons, Michael R. and Patrick Hess. "Day of the Week Effects and Asset Returns." Journal of Business 54 (October), 579-596.

Harris, Lawrence. "A Transaction Data Study of Weekly and Intradaily Patterns in Stock Returns." Journal of Financial Economics 16 (May 1986): 99-117.

Jaffe, Jeffrey F. "Special Information and Insider Trading." Journal of Business 47 (July 1974): 410-428.

Jensen, Michael. "The Performance of Mutual Funds in the Period 1945-64." Journal of Finance 23 (May 1968): 389-416.

Keim, Donald B. "The CAP, and Equity Return Regularities." Financial Analysts Journal (May/June 1986): 19-34.

Keim, Donald B. "Size-Related Anomalies and Stock Return Seasonality-Further Empirical Evidence." Journal of Financial Economics 12 (June 1983): 13-32.

Nicholson, S. Francis. "Price Earnings Ratios." Financial Analysts Journal 16 (July/August 1960): 43-45.

Reinganum, Marc R. "Portfolio Strategies Based on Market Capitalization." Journal of Portfolio Management (Winter 1983): 29-36.

Reinganum, Marc R. "Misspecification of Capital Asset Pricing: Empirical Anomalies Based on Earnings' Yields and Market Values." Journal of Financial Economics 9 (March 1981): $19-46$. 
Roberts, Harry V. "Stock Market 'Patterns' and Financial Analysis: Methodological Suggestions." Journal of Finance 14 (March 1959): 1-11.

Schwert, G. William. "Size and Stock Returns, and Other Empirical Regularities." Journal of Financial Economics 12 (June 1983): 3-12.

Seyhun, H. Nejat. "Insiders' Profits, Costs of Trading, and Market Efficiency." Journal of Financial Economics 16 (June 1986): $189-212$. 